\title{
Arquitectura románica en la provincia de Soria, 1856-2014. Marco historiográfico y metodológico
}

\section{Romanesque Architecture in the province of Soria, 1856-2014. Historiographical and methodological frame}

\author{
Josemi Lorenzo Arribas \\ Asociación Sostenibilidad y Patrimonio Cultural \\ e-mail: josemi20@hotmail.com
}

\begin{abstract}
RESUMEN
La historiografía del Románico en la provincia de Soria tiene tres etapas diferenciadas. Una inicial, que parte de los estudios de Eduardo Saavedra (1856) y se extiende hasta 1934, fecha de la lectura de la tesis doctoral de Gaya Nuño (La arquitectura románica en la provincia de Soria), cuya publicación, no obstante, se demora hasta 1946. La Guerra Civil y posguerra marcan el comienzo de la segunda etapa, transicional y sin grandes aportaciones. La última etapa se inaugura con la publicación de los tres volúmenes sorianos de la Enciclopedia del Románico en Castilla y León (2002). Esta obra ha multiplicado el conocimiento del patrimonio edilicio románico, acrecentado, después, por la labor de la Oficina Técnica del Proyecto Cultural Soria Románica (2007-2012), que estudió en profundidad e intervino en más de treinta edificios del sur de la provincia, y en cuyo marco se produjeron las lecturas de paramentos de los cuatro templos que aquí se presentan. Esta valoración historiográfica del Románico provincial excluye la capital, así como la catedral de El Burgo de Osma, el monasterio de Santa María de Huerta y la ermita de San Baudelio (Casillas de Berlanga).
\end{abstract}

Palabras clave: Historia del arte; Historia de la construcción; Edad Media; Gaya Nuño; iglesia de Ntra. Sra. de Campanario de Almazán; iglesia de Ntra. Sra. del Castillo en Calatañazor; iglesia de San Miguel en Caltojar; ermita de Santa María de Tiermes.

\section{ABSTRACT}

The historiography of Romanesque in the province of Soria has three different stages. The former one begins with Eduardo Saavedra's researches (1856) and it extends until 1934, when Gaya Nuño defends his PhD Thesis (La arquitectura románica en la provincia de Soria), which will not be published until 1946. The Spanish Civil War and the post-war period mark the beginning of the second stage, which is merely transitional, lacking any important contribution. The last stage begins with the publication of the three volumes of the Enciclopedia del Románico en Castilla y León (2002). These works have largely improved the knowledge of Romanesque architectural heritage, enhanced besides by the task undertaken by the technical office of the Cultural Project Soria Románica (20072012), responsible for studying and restoring more than thirty Romanesque buildings in the Southern part of province. It is within this working frame that the building recording of the churches here presented must be understood. This historiographical assessment about provincial Romanesque does not include those buildings sited in the capital city, the Cathedral of El Burgo de Osma, the Monastery of Santa Maria de Huerta and the hermitage of San Baudelio (Casillas de Berlanga).

Keywords: Art History; Construction History; Medieval Ages; Gaya Nuño; church of Ntra. Sra. de Campanario from Almazán; church of Ntra. Sra. del Castillo from Calatañazor; church of San Miguel from Caltojar; hermitage from Santa María de Tiermes.

Recibido: 26 mayo 2014. Aceptado: 7 septiembre 2014.

Cómo citar este artículo / Citation

Lorenzo Arribas, J.: "Arquitectura románica en la provincia de Soria, 1856-2014. Marco historiográfico y metodológico", Arqueología de la Arquitectura, 11: e017, doi.org/10.3989/arq.arqt.2014.171.

\section{Copyright}

(c) 2014 CSIC. Este es un artículo de acceso abierto distribuido bajo los términos de la licencia Creative Commons Attribution-Non Commercial (by-nc) Spain 3.0. 
A don Manuel García Torre (1947-2013), cura humilde y generoso, responsable del Archivo Diocesano de Osma-Soria, por todas las facilidades que me ofreció

La valoración historiográfica del Románico provincial que sigue se centra en las iglesias parroquiales y ermitas dispersas por la provincia. Se excluyen los edificios de la capital así como los estudios dedicados a los restos románicos arquitectónicos de la catedral burgense, al monasterio de Santa María de Huerta y a la ermita de San Baudelio (Casillas de Berlanga), que han atraído la atención ininterrumpida de los investigadores desde finales del siglo XIX y exigen tratamiento diferenciado. Se descarta también, porque desviaría del tema, la que únicamente se apoya en elementos decorativos (pintados o esculpidos) para realizar lecturas iconográficas y desde ellas inferir conclusiones cronológicas, que será citada solo en la medida en que interese al objetivo de estas páginas, que pretenden dar cuenta de estudios que aborden las fábricas edilicias.

La actual provincia de Soria cuenta con una alta densidad de edificios conservados de origen románico, la mayor parte religiosos, especialmente concentrados en la ciudad de Soria y en dos comarcas, la de San Esteban de Gormaz, y la llamada de la Sierra, esta última a pocos kilómetros al norte de la capital. De todos dio cuenta la Enciclopedia del Románico de Castilla y León, que a Soria le dedicó tres volúmenes, redactados por José Luis Hernando Garrido, José Manuel Rodríguez Montañés, Pedro Luis Huerta Huerta y Jaime Nuño González (Huerta, Rodríguez, Nuño, Hernando, Echeverría y Aragón 2002). Prácticamente nada de lo conocido escapó a su escrutinio, que hizo las veces de inventario de bienes inmuebles y muebles adscritos a este estilo, y que estudió y sistematizó lo que de Románico quedaba en más de trescientos edificios.

Como Rodríguez Montañés aseguraba en la Introducción a esta obra, «la primera característica del románico soriano es su anonimato» si se exceptúan los acercamientos a «los edificios más relevantes, o aquellos que descuellan por su exotismo, tales como San Miguel de Almazán, la catedral de El Burgo de Osma, la concatedral de San Pedro, Santo Domingo, San Juan de Rabanera, San Juan de Duero o San Nicolás de Soria, San Bartolomé de Ucero, San Baudelio de Berlanga, la iglesia de Tiermes o las de Caracena, entre otras» (Rodríguez 2002a: vol. I, p. 31). Esta afirmación puede sostenerse también en el año 2014, pero yendo incluso más allá, porque ni siquiera algunas de estas construcciones paradigmáticas están bien explicadas desde el punto de vista arquitectónico o de la historia de la construcción. Ocurre en numerosas ocasiones, y esta no es excepción. Si interesa una construcción románica, se deja de dar cuenta de las transformaciones que el edificio haya acumulado con el paso de los siglos y se desatiende su evolución.

Por otro lado, casi toda la bibliografía que ha prestado atención al Románico soriano se ha centrado en cuestiones iconográficas, sea de las representaciones esculpidas, sea de las pintadas. En las primeras, se insiste una y otra vez sobre si la filiación de las labras pertenece a los llamados primer y segundo Maestro de Silos o si, por el contrario, es más influjo aragonés el que prima en las improntas. Los estudios que dejan aparte la escultura monumental o bien se centran en algún elemento del mobiliario litúrgico, como las pilas bautismales (García 2007), o abordan en detalle un caso concreto o un pequeño número de muestras. Si trasladamos el enfoque a cuestiones arquitectónicas estructurales, la palma se la llevan los análisis de las galerías porticadas, consideradas elemento identitario en la sintaxis constructiva edilicia del Románico castellano, con muchas y buenas muestras representadas en la provincia.

Así las cosas, dos hitos se pueden establecer en la historiografía sobre el Románico en la provincia de Soria, y consiguientemente tres etapas. Uno, el citado al comienzo de estas páginas, la publicación de la parte soriana de la Enciclopedia del románico, que vio la luz cuando se estrenaba este siglo actual (Huerta, Rodríguez, Nuño, Hernando, Echeverría y Aragón 2002). El otro se retrotrae hasta 1934, año en que Juan Antonio Gaya Nuño redacta El Románico en la provincia de Soria, publicado doce años después. Estos dos jalones diferencian tres claras etapas de una bibliografía que trata de dar cuenta estructural de la evolución de los edificios, a la que nos vamos a referir.

\section{ETAPA INICIAL, HASTA 1934}

El Románico en Soria comenzó, como no podía ser de otra forma, siendo arte bizantino, pero tempranamente tendrá reivindicación adaptada a la nueva terminología que llega allende los Pirineos y se transmuta en Románico desde pronto, gracias al tarraconense Eduardo Saavedra, académico, ingeniero, arqueólogo y arabista, que en 1856 estudió las ruinas de San Juan de Duero, y las de San Nicolás tres años después, ambas en la ciudad 
de Soria, inmediatamente antes de demostrar el emplazamiento de Numancia en la muela de Garray y acabar definitivamente con varios siglos de discusión sobre su correcta ubicación (Saavedra 1856 y 1859). Un esfuerzo personal significativo, que venía a interesar a foráneos en el patrimonio cultural soriano, habida cuenta de que la mayor parte de los viajeros que desde el siglo XVI hasta el XIX recorrieron las tierras de la mitad norte peninsular apenas pasaron por Soria (tampoco los fotógrafos pioneros), o que esta quedó fuera de títulos referenciales como Viage de España (Ponz 1785) que tan solo visita Medinaceli y Santa María de Huerta, monasterio del que sí ofrece información, o Recuerdos y bellezas de España (Quadrado y Parcerisa 1855, 1865a, 1865b), que aborda todas las provincias de la actual Comunidad Autónoma de Castilla y León, excepto Soria y Burgos.

Las iglesias de la capital fueron, por tanto, las primeras de las medievales de la provincia en atraer la atención científica (vid. el clásico de Rabal, 1889). A su estudio se consagró el arquitecto Teodoro Ramírez Rojas, miembro de la Real Academia de Bellas Artes de San Fernando, que dejó varios opúsculos. Uno generalista (Ramírez 1894a), de 39 páginas, publicado por haber sido premiado en un Certamen Científico-Literario local, y dos más, uno sobre posibles emplazamientos para la portada de la iglesia de San Nicolás (Ramírez 1894b), y otro sobre San Juan de Duero (Ramírez y Lorenzo 1904). Autoridades nacionales como Lampérez y Mélida se interesaron también por este Románico. El primero escribió sobre esta última iglesia otra aportación (Lampérez 1904), y el último publicó dos estudios sobre San Juan de Rabanera (Mélida 1910a y 1910b). El propio Lampérez, más allá de estos breves acercamientos, contribuyó a dar a conocer a un público mayor las iglesias de Santo Domingo, San Juan de Duero y San Juan de Rabanera al incluirlas en su monumental Historia de la arquitectura cristiana española en la Edad Media (Lampérez 1908: 508-514, más una pequeña reseña de la ruina de la iglesia de San Nicolás: 516).

Sobre la provincia, de esta época inicial apenas destacan los estudios monográficos sobre Santa María de Huerta (Pérez-Villamil 1875; Lampérez 1901b; Cerralbo 1908; y González 1929), la iglesia de San Miguel de Almazán (Lampérez 1901a. Fig. 1); la ermita, ya sin culto, de San Baudelio en Casillas de Berlanga (Álvarez y Mélida 1907; Garnelo 1924), la ermita San Bartolomé de Ucero (Ramírez 1907-1908; reseñada en Lampérez 1908: 516), la ermita de Santa María de Tiermes (Sentenach 1911) y las iglesias de San Esteban de Gormaz

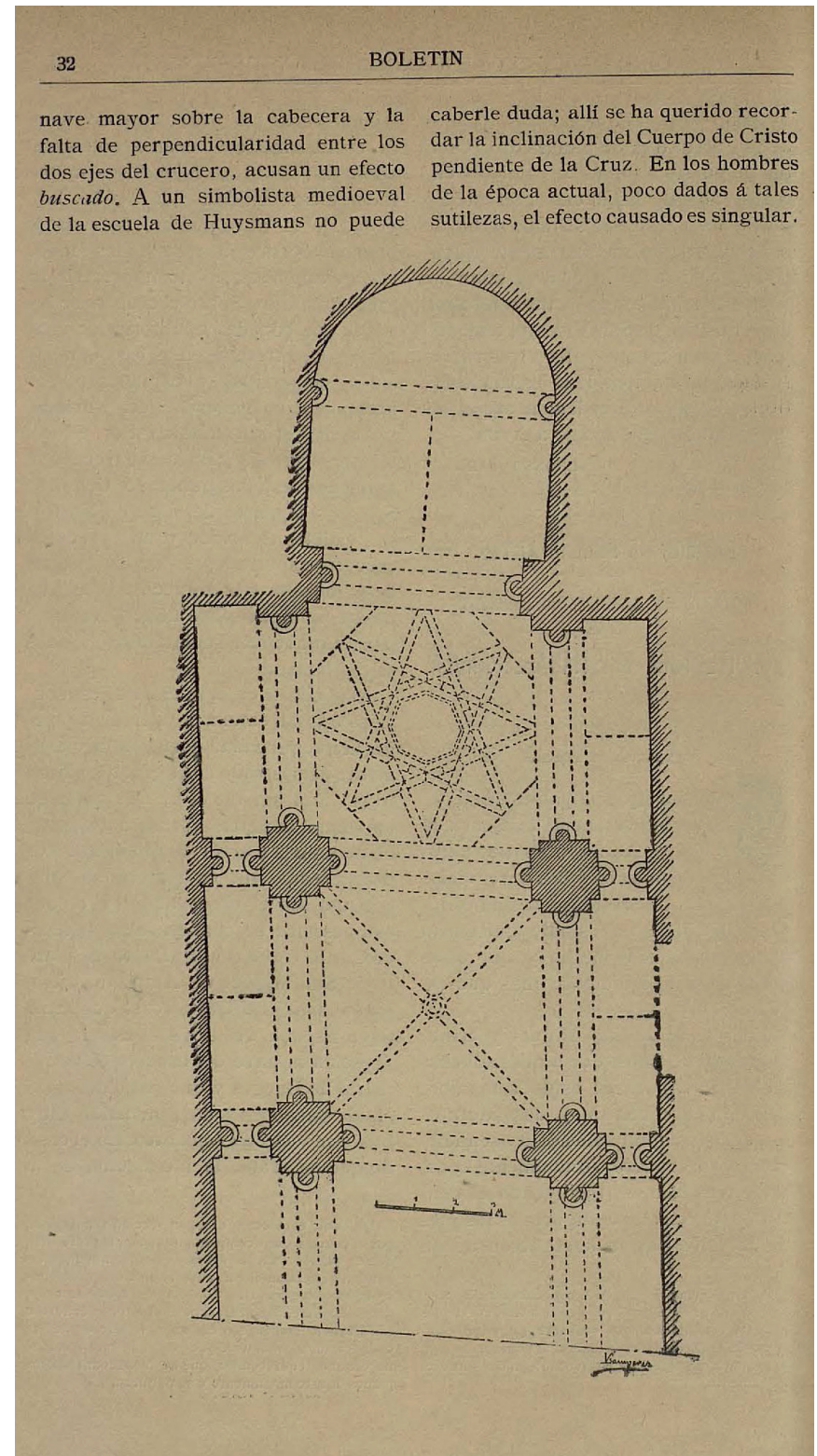

Fig. 1. Planta de la iglesia de San Miguel de Almazán levantada por Vicente Lampérez (1901a: 32), primer acercamiento riguroso al Románico provincial de Soria.

(Artigas y Corominas 1932; Álvarez y González 19341935). La iglesia de San Miguel también mereció cuatro líneas en la Historia de Lampérez, única de las que cita de Soria que no contaba con estudio previo (Lampérez 1908: 517).

Sin duda, el esfuerzo más importante, por su ambición, alcance y rigor, se debe al arqueólogo (y fotógrafo) Juan Cabré Aguiló, autor del Catálogo Monumental de la provincia de Soria. Esta obra formaba parte del magno proyecto catalogador que se comenzó en España en 1900, y que quedaría malogrado. Los ocho tomos que 
escribió (con fotografías propias) y presentó en 1916 quedaron lamentablemente inéditos (desde hace poco, es consultable en línea el original), y por tanto han sido muy poco conocidos y aprovechados.

...en la provincia de Soria hay bastantes más iglesias o ermitas románicas que no describiré minuciosamente $1^{\circ}$ Porque algunas de esas no las he visitado y su conocimiento lo debo a investigaciones realizadas después de mis viajes.

Nada extraño es que algún monumento interesante se nos pase por alto a pesar que he recorrido la provincia de Soria en todas sus direcciones, por ferrocarril, en carruaje, a caballo y aun a pie. Esta provincia es muy extensa y montañosa y consta de trescientos hayuntamientos (sic), número mayor de poblaciones al plazo fijado de días para la presentación del Catálogo. Con un año de tiempo para tomar datos a la vista y luego ordenarlos. No se pueden hacer milagros.

Y $2^{\circ}$, porque la mayoría de las que en breve citaré, o bien hállanse muy desfiguradas por reparaciones posteriores, o carecen de alto interés por la sencillez de sus elementos arquitectónicos (Cabré 1916: tomo VI, 118-119).

El tomo VI del Catálogo, por tanto, lo dedicó a «Arquitectura cristiana de la Edad Media», y el VII a «Catedral del Burgo de Osma y Monasterio de Santa María de Huerta». En el primero de ellos, daba cuenta de seis iglesias capitalinas, la ermita de San Baudelio de Casillas de Berlanga, las iglesias de Almazán, San Esteban de Gormaz, Caracena, Rejas de San Esteban, y las parroquiales de Omeñaca, Villasayas, Barca, Cerbón, Ágreda, Fuensaúco, Tozalmoro, Peroniel del Campo, Aldealpozo, Bordecorex, Retortillo, Valdenebro, Paones, Tera, Muro, y las ermitas de Brías, Garray, Gormaz, Ucero, así como las ruinas de la iglesia de San Pedro el Viejo (San Pedro Manrique). Hubo espacio también para las cuatro iglesias que introducen estas páginas, con una extensión en texto que osciló tan solo entre media y una página manuscrita, pero con aporte gráfico y fotográfico adicional: Nuestra Señora de Campanario de Almazán (Cabré 1916), la ermita de Santa María de Tiermes (Cabré 1916: 87-89; seis fotografías y una planta), Caltojar (Cabré 1916: 99-101; seis fotografías, marcas de cantero y una planta. Fig. 2) y Nuestra Señora del Castillo de Calatañazor (Cabré 1916: 108; dos fotografías).

Apenas accesible este gran Catálogo, la primera visión provincial de conjunto que se publicó fue una obra de otra naturaleza: Soria. Guía artística de la ciudad y provincia, volumen que firmaron Blas Taracena y José

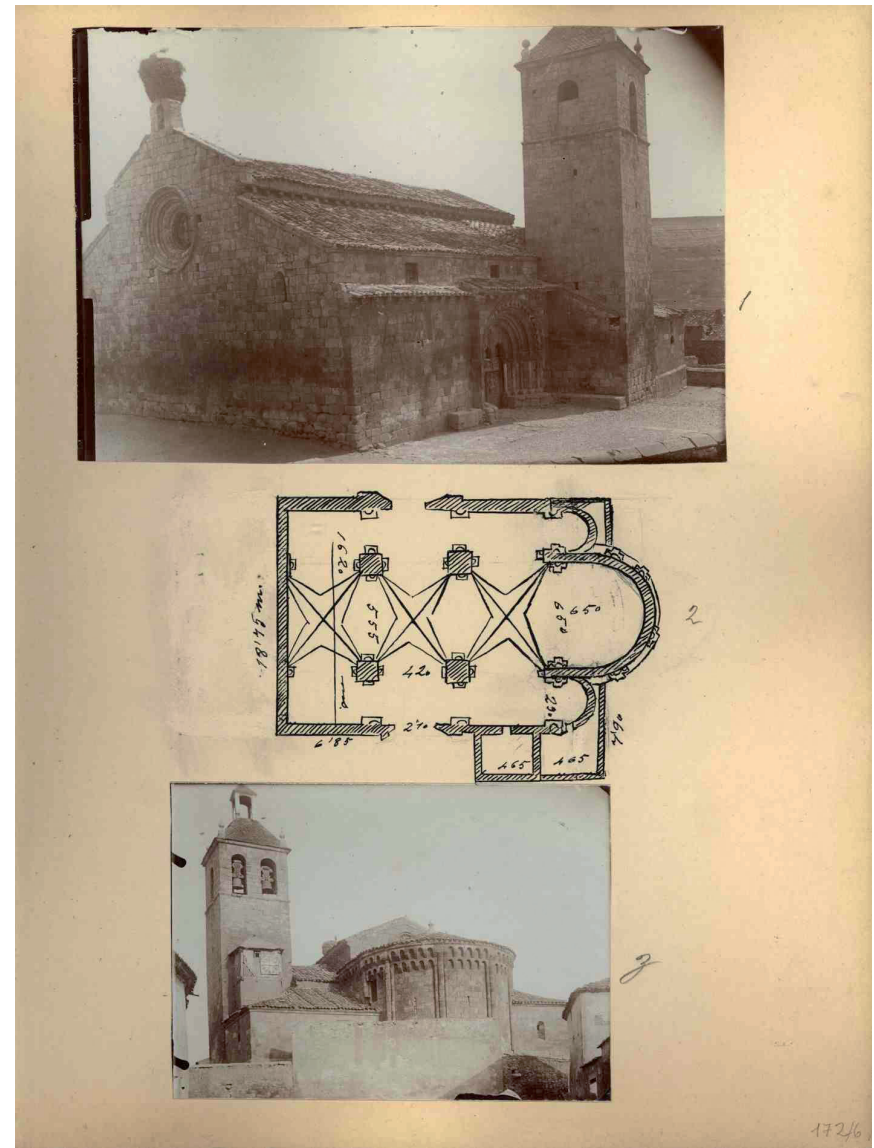

Fig. 2. Página del inédito Catálogo monumental de la provincia de Soria de Juan Cabré, con la planta y dos fotografías del costado sur de la iglesia de San Miguel Arcángel de Caltojar (Cabré, inédito: vol. 6, lám. LXXIX).

Tudela (1928) ${ }^{1}$. Muy sumaria en lo que a descripciones arquitectónicas se refiere, supondrá, sin embargo, una pauta a seguir por la autoridad de ambos autores y su amplia difusión. Si esta Guía iba dirigida a un público general, a otro específico y muy especializado se dirigieron las Memorias de excavaciones que diera a la luz en los años veinte el primero de estos ${ }^{2}$. Son importantes porque se comenzaba una metodología de publicación y registro de materiales de trabajo que quedaría tristemente interrumpida con la Guerra Civil y posguerra en cuanto al

\footnotetext{
En la $6^{\text {a }}$ edición (corregida y aumentada) de la Guía (Taracena y Tudela 1997) se dedican breves líneas a las iglesias que aquí interesan, la adnamantina de Campanario (Taracena y Tudela 1997: 212), Nuestra Señora del Castillo (Taracena y Tudela 1997: 169-170), Nuestra Señora de Tiermes (Taracena y Tudela 1997: 200-201) y Caltojar (Taracena y Tudela 1997: 222-223).

2 Como las correspondientes a las campañas de 1924, 1928 y 1932 en la provincia de Soria (Taracena 1926, 1929 y 1932) o las de 1925-1926, relativas a las provincias de Soria y «Logroño» (Taracena 1927). José Ramón Mélida publicó las de Numancia en sus campañas de 1916-1917, 1919-1920, 19201921 y 1923 (Mélida 1918 y 1923; Mélida y Taracena 1920).
} 
diálogo científico se refiere entre tres disciplinas en liza, Arqueología, Historia e Historia del Arte.

En los años veinte, esta labor previa de investigación se vio reconocida por el interés de figuras referenciales patrias como Gómez-Moreno (1923), así como internacionales. Soria todavía no estaba situada en el mapa que se traza en la polémica «Spain or Toulouse» que protagonizan Arthur Porter y Émile Mâle, y que tuvo por objeto dilucidar o no la precedencia de la zona tolosana como cuna del Románico europeo, según quería el historiador francés, frente a lo cual el norteamericano saca a la palestra los grandes centros de la ruta jacobea, Santo Domingo de Silos (que se convirtió en piedra de toque del debate) y otros catalanes (Porter 1924. Un análisis de los posicionamientos que animaban esta discusión en Mann 1997). Porter, incluso, reprodujo las esculturas en bulto del pórtico de Tiermes pocos años después (1928, vol. II, lám. XLCV). Soria entra en la cartografía del Románico hispano gracias a una investigadora norteamericana, Georgina Goddard King (1871-1939). También estudiosa del Camino de Santiago, se deja seducir por el influjo musulmán en el arte medieval, particularmente en la arquitectura (King 1923; le seguirá Lambert 1928), y llega a tematizar en un artículo «The problem of the Duero», en que trata de Zamora, Plasencia y Soria capital, ciudad adonde viajó en más de una ocasión (King 1925). Al margen de sus teorías sobre el posible influjo oriental de la escultura monumental (que llega a vincular al Extremo Oriente), lo cierto es que la mitad de las 22 láminas que incluye en el artículo se refieren a Soria (11 a la capital, y una dedicada a San Miguel de Almazán). Esta década, por otro lado, asistirá a la publicación de dos Catálogos monumentales sobre trabajo de campo realizado veinte años antes, los correspondientes a las provincias de León y Zamora, ambos firmados por Manuel Gómez-Moreno, figura ya de autoridad en el panorama internacional (Gómez-Moreno 1925 y 1927). Aunque trascienden la época románica, los estudiosos internacionales de este estilo, particularmente norteamericanos, saludarán alborozados esta puesta a disposición de datos (y láminas) inéditos, nuevos edificios y bienes muebles datados entre los siglos $\mathrm{X}$ a XIII ${ }^{3}$.

\footnotetext{
3 No escatimó elogios Arthur K. Porter, que entendió inmediatamente la revolución que supuso la publicación del Catálogo leonés en un artículo-reseña que no dejaba lugar a dudas sobre el giro de tuerca que habría de provocar esta obra, como así fue: «As we turn the pages we receive shock after shock; one after another, unknown monuments of international importance are published, concisely, but accurately and adequately; the author scarcely betrays that he is aware of the significance of what he is making known; he gives the facts and leaves the scholarly world to whistle» (Porter 1926: 236).
}

Este era el panorama cuando un joven estudiante soriano, Juan Antonio Gaya Nuño, se licenció en 1932 en la Universidad Central de Madrid en Filosofía y Letras y decidió embarcarse ese mismo verano en el ambicioso proyecto de dedicar su tesis doctoral al estudio del Románico soriano capitalino y provincial, animado por Manuel Gómez-Moreno.

\section{JUAN ANTONIO GAYA NUÑO Y SU TESIS DOCTORAL (1934) PUBLICADA EN 1946}

La elección del tema fue, sin duda, decisión valiente por los escasos precedentes de que disponía, pues ni había mucho publicado, como se ha visto, ni apenas había tradición de monografías territoriales sobre Románico en las provincias fronterizas con Soria, si exceptuamos la obra de Ricardo del Arco y Garay sobre la región pirenaica (Arco y Garay 1932), publicada el mismo año de la licenciatura de Gaya (este autor, sobre Huesca, publicará el Catálogo monumental en 1942). No parece que pudiera consultar el inédito Catálogo de Cabré para la redacción de su tesis doctoral. El esfuerzo se tuvo que hacer sin apenas precedentes, como se comentó. Escribirá el soriano en una obra posterior: «Recordaré cuán poca era la bibliografía existente de carácter responsable, limitada a la obra de Puig y Cadafalch para lo catalán y a títulos abundantes, pero de escaso foco visual, en lo que respecta a otras regiones» (Gaya 1962: 5-6).

Juan Antonio Gaya Nuño es, por tanto, la primera persona que se afana en estudiar sistemáticamente el Románico de la provincia de Soria con ambición territorial (Lorenzo 2013). La tesis llevó por título La arquitectura románica en la provincia de Soria, y a modo de homenaje lo he escogido para titular estas páginas.

En la Facultad de Filosofía y Letras de la Universidad Complutense, entonces Central, donde se defendió, no era habitual una tesis sobre Historia del Arte en esos años, pues primaban temas literarios o historiográficos. La investigación comenzó en el verano de 1932 y parece que estaba terminada año y medio después, a finales del siguiente (Gaya 1962: 5). Para hacerla, además de consultar una exhaustiva lectura de prácticamente toda la bibliografía existente, viajó, a pesar de las limitaciones de la época, por grandes sectores de la provincia, con el fin de conocer de primera mano (y de fotografiar) el mayor número posible de edificios, y consultó, de primera mano o a través de la ayuda de terceros, ciertos libros de fábrica. El arqueólogo Blas Taracena, paisano 
y amigo, hubo de guiarle en estos primeros pasos. A finales de 1933 tenía preparado el manuscrito para su defensa. Ese mismo año el propio Taracena firmó un estudio contextual pionero en que por primera vez se abordaba un tema llamado a ser referencial: las galerías porticadas románicas y la de la ermita de Tiermes, que aparece reflejada y representada en planta (Taracena 1933: 418-420 y lám. 5).

El tribunal de la tesis estuvo compuesto por los catedráticos José Ferrandis (presidente), Elías Tormo (Historia del Arte), Manuel Gómez-Moreno (Arqueología Arábiga), Andrés Ovejero (Literatura general e historia del arte) y el entonces auxiliar de la cátedra de Historia del Arte, Enrique Lafuente Ferrari. Posiblemente la lectura se produjo el lunes 22 de enero de 1934, lo que celebró el diario local La Voz de Soria unos días después ${ }^{4}$.

Por razones desconocidas, no se conserva el manuscrito en el archivo del Servicio de Tesis Doctorales y Publicaciones Académicas. En la Biblioteca de Tesis de la Universidad Complutense tan solo queda como huella de la misma una copia de una ficha manual donde figura: «No se recibió ningún ejemplar en el Archivo. Retenida en la Fac. de $G^{\text {a }}$ e Historia», pero en dicha Facultad no queda nada anterior a 1946. Tampoco hay ninguna copia del manuscrito en el Legado Gaya Nuño, ni siquiera borradores, aunque sí se encuentran algunos de sus planos, plantas y dibujos.

Una vez defendida, inició inmediatamente gestiones con la editorial Plutarco para su publicación. El epistolario permite seguir el itinerario y avatares. Resumidamente, la primera comunicación conservada entre autor y editorial data del 2 de abril de $1934^{5}$ (Fig. 3), y la última de 20 del mismo mes de 1936, en que se le enviaban galeradas para la corrección hasta la página $80^{6}$. En ese ínterin y paralelamente a la negociación para la publicación del libro tuvo lugar su primera incursión editorial stricto sensu sobre Románico en la prensa generalista, y permitió al soriano dar a conocer una noticia de actualidad en la prensa, el descubrimiento, tres meses después de leída su tesis, del frontal de altar pétreo románico procedente de la iglesia de San Nicolás en Soria. Simultáneamente, el médico e historiador Francisco

\footnotetext{
30 de enero de 1934 , p. 3.

5 Legado Gaya Nuño. Caja 15, P 282. Sito en el Centro Cultural Gaya Nuño (Soria), y gestionado, cuando se consultó la documentación, por Caja Duero. Falta por ver en qué condiciones queda, y quién y cómo lo gestiona cuando acaben los actuales procesos de fusión de cajas de ahorro y su conversión en bancos.

${ }^{6}$ Legado Gaya Nuño, Caja 1, A AN 118.
}

Layna Serrano, presidente de la Comisión Provincial de Monumentos de Guadalajara, publicó la contraparte a la tesis gayana de provincia vecina, La arquitectura románica en la provincia de Guadalajara (Layna 1935; Lorenzo 2012a). Cada uno era consciente de las investigaciones del otro. En carta a Blas Taracena, de octubre de 1934, se lamenta Layna Serrano: «Menciono la obra de Gaya, pero como está inédita, no puedo referirme a ella como quisiera...» ${ }^{7}$. Pero la Guerra Civil interrumpió el avanzado estado de publicación del libro, acontecimiento fatídico que, además de la devastación cultural que produjo en el panorama español (apreciable en el campo que nos ocupa), afectó directamente al joven doctor. Gaya Nuño fue encarcelado por su militancia republicana durante la contienda al fin de esta, en abril de 1939.

No sería hasta 1946 cuando finalmente el libro es publicado por el Instituto Diego Velázquez del CSIC, con quien el historiador del arte colaboró a la salida de prisión (obtuvo la libertad provisional en 1943). En la edición el título original de la tesis se abrevió como $E l$ Románico en la provincia de Soria. La monografía fue ampliamente reseñada y acogida con todos los parabienes por su calidad, lo que hizo que el Románico soriano diera un salto de gigante en el panorama internacional que antes solo había conocido la zona catalana en cuanto se refiere a publicación de monografías regionales específicamente dedicadas al Románico. Desde luego, Gaya actualizó, para su edición final, numerosos datos con respecto a la versión de 1934 (Gaya 1946. Fig. 4). Porter ya no vivía para disfrutarla, pero se cumplía un antiguo deseo suyo que formuló cuando se publicó el Catálogo monumental de León: «we must know Castile and Galicia and Navarre and all the other provinces of Spain as we now know Leon» (Porter 1926: 236).

Aunque lo cualitativo acabe imponiéndose, los números también aproximan a la relevancia de esta obra, que da cuenta de 106 edificios de los que, poco o mucho, se dice algo y se ponen en el mapa literalmente, porque se incluye uno que muestra gráficamente cómo la «mancha románica» en la provincia no es algo anecdótico sino constitutivo. Acompaña al texto (285 páginas) una exhaustiva documentación fotográfica, y no es detalle menor, con 278 tomas (un tercio de las cuales realizadas por el propio Gaya), que corresponden a 83 localidades distintas y abarcan un total de 102 edificios. A la documentación fotográfica hay que sumar los dibujos, con

Legado Gaya Nuño. Caja 12, IC L 88. 


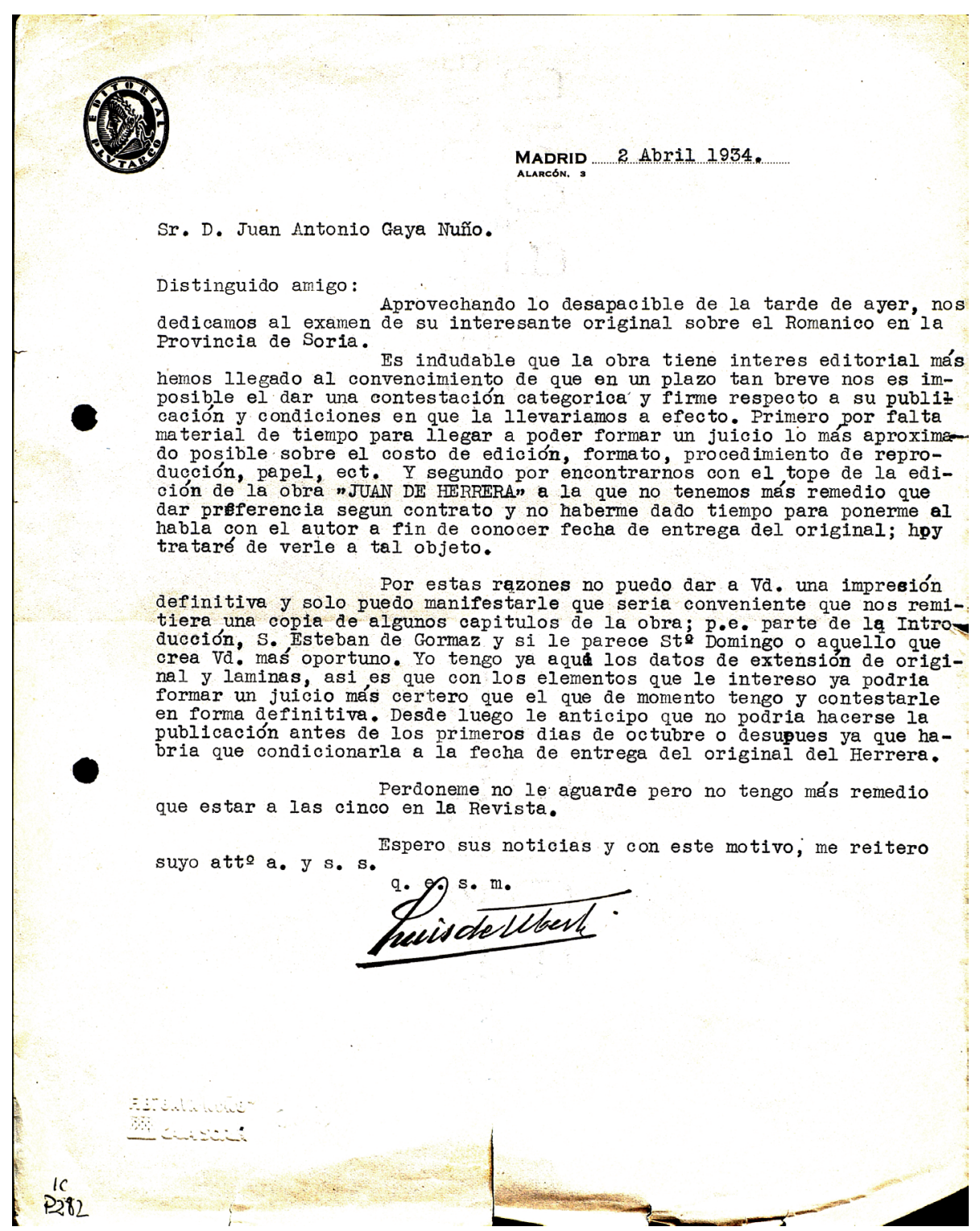

Fig. 3. Primera carta (de 2 de abril de 1934) conservada en el Legado Gaya Nuño del epistolario entre el soriano y la editorial Plutarco para la malograda edición de su tesis doctoral (Legado Gaya Nuño, Caja 15 P 282), proyecto que quedaría interrumpido por la Guerra Civil. La tesis, La arquitectura románica en la provincia de Soria, se había defendido el 22 de enero del mismo año. escala gráfica, básicamente correspondientes a plantas. Este apartado gráfico aseguró las citas a la obra de las generaciones de investigadores que se acercaran al Románico hispano en adelante, tan escaso de imágenes de edificios «menores». Se puede afirmar que esta obra supuso tanto un análisis (de muchos ejemplos desconocidos o apenas estudiados) como una síntesis (de lo que se sabía).

En la posguerra, el Románico de la provincia de Soria no despertará una atención preferente. Como en otros aspectos de la historia general, por tanto, la Guerra Civil marcará un hito negativo en lo que a historiografía románica, metodología y reflexión se refiere. El propio Gaya Nuño redactará, ya excarcelado y dedicado a otros menesteres, la parte correspondiente a Castilla del volumen $\mathrm{V}$ de Ars Hispaniae, dedicado al Románico ibérico, cuya redacción comparte con José Gudiol Ricart (Gudiol y Gaya 1948), resumiendo mucho las líneas y planteamientos ya publicados, con referencias de pasada a la ermita de Tiermes y a la parroquial de Caltojar (Gudiol y Gaya 1948: 300 y 315).

Una excepción personal a este panorama se concentra en la figura del arqueólogo soriano Teógenes Ortego (Cortés 1988). En su catálogo bibliográfico hay media docena de artículos publicados entre 1952 y 1975, casi todos en la revista local Celtiberia, que comenzó su andadura en 1951, los cuales aportan nuevos elementos de comprensión, bien a templos conocidos (Ortego 1952, 1957 y 1959), o bien primeras investigaciones sobre otras tantas iglesias a las que nadie había prestado atención hasta el momento, como la ermita de la 


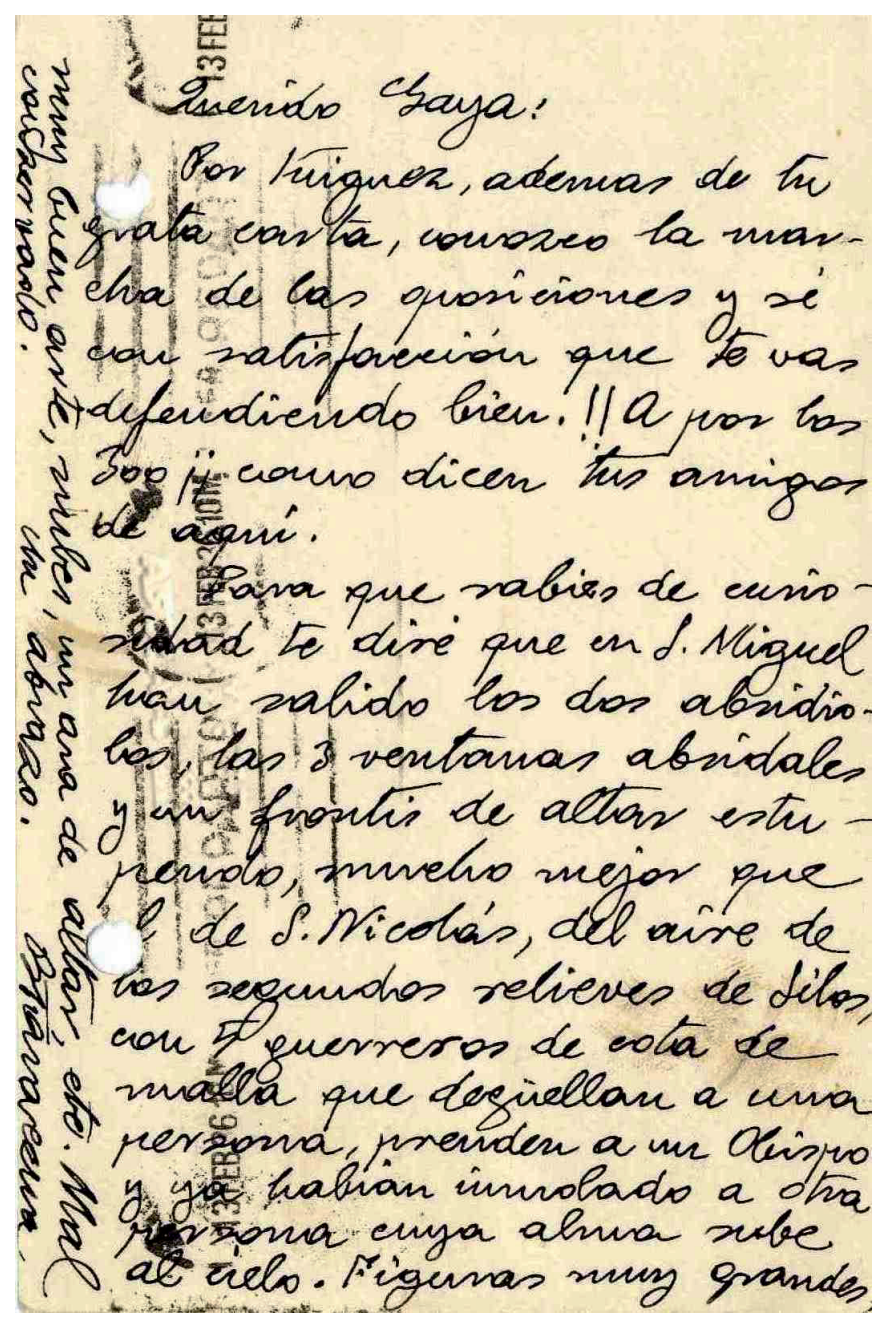

Fig. 4. «Para que rabies de curiosidad, te diré que en San Miguel [de Almazán] han salido los dos absidiolos, las 3 ventanas absidales y un frontis de altar estupendo, mucho mejor que el de S. Nicolás [de Soria], del aire de los segundos relieves de Silos», postal de Blas Taracena a Juan Antonio Gaya Nuño franqueada el 12 de febrero de 1936 (Legado Gaya Nuño. Caja 18 T 14).

Virgen del Val en Pedro (Ortego 1958), la parroquia de San Bartolomé en Viana de Duero (Ortego 1969), o las ruinas de la ermita de San Esteban en Alcozar (Ortego 1985), así como algunos libros en cuyas páginas se tratan también iglesias románicas (Ortego 1973, 1975, 1987). De hecho, si la lectura correcta que Ortego hizo de la fecha (año 1082) que se ofrece en un canecillo de la galería porticada de la iglesia sanestebeña de San Miguel la hubiera conocido Gaya Nuño (el arqueólogo la publicó dos décadas después: Ortego 1952), quizá los derroteros sobre el origen del Románico extremadurano hubieran ido por otra dirección (Álvarez y González la publicaron con otra lectura, año 1119 , en su artículo de 1934-1935. Sobre este asunto, Lorenzo 2009). Otros autores han tratado desde un punto de vista documental algunos monasterios sorianos de origen medieval (Zamora 1951, 1952 y 1953), iglesias como la parroquial de Andaluz (Lafuente 1971), y también desde el conocimiento arqueológico (Barrio, Lerín, Tarancón, Ruiz y Arellano 1991). Situaciones de urgencia, como la ermita de la Virgen del Vallejo en Alcozar, y la presencia de un fuerte movimiento popular de denuncia en pro de su recuperación (Olañeta 2006) han provocado también la investigación arquitectónica sobre dicho templo (Amo y Frías 1995; Yusta, Diestro, Esteras, Gonzalo y Lorenzo 2010), un ejemplo lamentablemente aislado de colaboración entre técnicos y comunidades locales.

Fallecido ya el gran conocedor del Románico soriano (Gaya Nuño muere en 1976), María Elena Sáinz Magaña realizó su tesis en 1983 con el título El románico soriano. Estudio simbólico de los monumentos, epígrafe que refleja bien el interés del acercamiento a este patrimonio. La tesis, de dos volúmenes, de los cuales el segundo se dedicó íntegramente a un apéndice fotográfico, comprendió las comarcas de la histórica Comunidad de Villa y Tierra de Soria, y las de Ágreda y Almazán, dejando fuera, entre otras, las de San Esteban de Gormaz o Berlanga, donde se sitúan tres de las cuatro iglesias que se analizan en este monográfico. Sobre el tema de esta tesis doctoral, reprografiada por la propia Universidad un año después de su defensa, tan solo se publicaron dos brevísimos artículos sobre aspectos parciales de la misma (Sáinz 1983 y 1984b), pues la autora no dio continuidad a esta línea. Casi paralelamente, se publicó el primer volumen de la Historia de Soria, dirigida por José Antonio Pérez Rioja, en que Izquierdo Bértiz dedica unas páginas a «Arte románico» (1985), que vienen a ser un estado de la cuestión. Medio siglo después de redactada la tesis doctoral de Gaya Nuño, y cuatro décadas después de publicada, el panorama crítico no había cambiado demasiado.

Otros libros, de naturaleza variada, han sintetizado aspectos básicos de las construcciones arquitectónicas de la provincia, pero no han incluido aportes novedosos, bien por ser inventarios generales de patrimonio más centrados en bienes muebles (Manrique, García y Monge 1989; de las iglesias aquí estudiadas, tan solo se dedican tres breves páginas a la de Calatañazor, en 170-173), o trabajos a medio camino entre la divulgación histórica y la turística (Lojendio y Rodríguez 1981; Enríquez 1986). Bango ofreció su versión más extensa del Románico provincial de Soria en unas páginas insertas en una obra sobre estas manifestaciones 
en la totalidad de la comunidad castellanoleonesa, siguiendo el esquema de Gaya Nuño en secuencia discursiva y casi hasta en los ejemplos (Bango 1997: 238-273; Gudiol y Gaya 1948: 296-315), salvo en algún detalle. El prometedor listado final de 117 iglesias románicas (todo o en parte) defrauda al comprobar que se sigue al pie de la letra ${ }^{8}$ lo que el erudito soriano publicara medio siglo antes (Bango 1997: 268-273). Tan solo se añaden a la nómina las parroquias de Alparrache, Ojuel, Osona, Palacio de San Pedro, Pozalmuro, y una ermita románica de la que no se ofrece advocación en Magaña (parece tratarse de Ntra. Sra. de Barruso ${ }^{9}$ ). Por el contrario, sorprende la inclusión de los restos de muros «románicos» de la ermita de Santa Ana en Calatañazor, que no consta su conservación. Otros trabajos han analizado desde antiguo la influencia musulmana en ciertas soluciones arquitectónicas, como las bóvedas (King 1923; Torres 1940; Lambert 1928 y 1935; Momplet 1992a y 1992b) o, más recientemente, iconográficas (Monteira 2004 y 2005, y diversos estudios más, que han culminado ahora con un libro -2012-, en realidad su tesis doctoral, donde sistematiza su línea de investigación en torno a la lectura anti-islámica de ciertos iconogramas). Ciertos autores, los menos, siguieron la antigua y buena costumbre de publicar resultados de intervenciones arqueológicas. Basten los ejemplos de las excavaciones parciales realizadas en las iglesias de San Miguel de San Esteban de Gormaz (Larrén 1984), San Pedro de Caracena (Morales y Borobio 1991 y 1992), y la parroquial de Castillejo de Robledo (Morales y Borobio 1995), sin que falte alguna aportación que estudia específicamente un edificio desde sus propios elementos constructivos y estructurales, como la parroquia de San Miguel Arcángel de Andaluz (Yusta 1993), o pequeñas monografías que centran el foco en iglesias románicas de la mitad norte de la provincia apenas tratadas, siempre menos estudiadas que sus homólogas meridionales (Recio 1981; Quiñones 1983, 1984 y 1985).

A falta de otras perspectivas y enfoques, la mayor parte de las iglesias se han pretendido datar por la calidad escultórica de sus elementos decorativos, con insistencia

\footnotetext{
8 Erratas incluidas, como denominar Miño de Medina a Miño de Medinaceli; «Monjía» debe tratarse de la ermita de la Virgen de la Valvanera en Fuentetoba; en Ólvega repite la afirmación gayana, hecha de pasada, sobre posibles restos románicos en la iglesia parroquial, que no son tales, y se obvian las ermitas románicas de San Marcos y San Bartolomé. Por error, se cita Romanillos de la Sierra, quizá en referencia a Romanillos de Medinaceli.

9 Otras dos ermitas de origen románico, en ruinas, conserva Magaña en su término: San Salvador y, casi desaparecida, San Miguel.
}

en tipologías de las que derivan frecuentemente consideraciones casi autorreferenciales. En este sentido, ha sido particularmente bien acogida la influencia en muchas de ellas del llamado «Segundo Taller de Silos» (con motivo del IX Centenario de la abadía burgalesa, tres estudios incidieron en ese hecho: Ruiz Ezquerro 1990, Izquierdo 1990 y Sáinz 1990). Aunque no sea motivo de estas páginas, añado que los bienes muebles románicos corrieron en esta época peor suerte bibliográfica en trabajos de conjunto (Hernández Álvaro 1984; una reflexión parcial en Diestro y Lorenzo 2010). Más asistemáticamente, se deben referenciar en este punto los Catálogos de las dos muestras de Las Edades del Hombre realizadas en la provincia, en la catedral de El Burgo de Osma (La ciudad 1997) y en la concatedral de Soria (Paisaje interior 2009). Con motivo de esta última exposición se hizo una amplia reflexión sobre las galerías porticadas románicas sorianas (Gonzalo, Esteras y Lorenzo 2009), tema que sigue atrayendo a los investigadores desde la reconceptualización que hiciera Bango de ellas (Bango 1975; importante también Ruiz Montejo 1980), cuatro décadas después del artículo de Taracena (Taracena 1933), y continúa produciendo más bibliografía (Salgado 2012, de entre sus varios estudios). Por lo general, esta bibliografía no ha contado, salvo contadísimas excepciones, ni con planimetrías buenas ni con planimetrías nuevas, instrumento de trabajo básico y previo cuando de entender la arquitectura se trata.

\section{LA ENCICLOPEDIA DEL ROMÁNICO EN CASTILLA Y LEÓN. SORIA (2002)}

Sus tres volúmenes de esta constituyen a día de hoy una obra referencial, y por su ambición, extensión y resultados están llamados a estar vigentes durante varias décadas, del mismo modo que la obra de Gaya Nuño hizo en las precedentes (Huerta, Rodríguez, Nuño, Hernando, Echeverría y Aragón 2002). En casi mil quinientas páginas se vertió el trabajo de campo realizado por un equipo compuesto por cuatro personas entre 1998 y 1999, que comenzaban un proyecto que tuvo como primer objetivo, alcanzado años después, estudiar entera la Comunidad de Castilla y León. El primer resultado obvio fue que la nómina de los edificios existentes que conservaban elementos arquitectónicos románicos se acrecentó en más del doble de los conocidos hasta entonces, alcanzando cerca de los doscientos cincuenta que contaban con estructura o elementos románicos monumentales. 
Estos volúmenes contaron bibliográficamente con dos adelantos. Por un lado, en forma de exposición y catálogo, realizado por los mismos autores (Soria Románica 2001). Por otro, la publicación aislada de la parte correspondiente al Románico de la capital, pero desprovista de aparato crítico (Hernando, Huerta, Nuño y Rodríguez 2001). Además de estos precedentes, también ha tenido una «secuela» más accesible al público general, el resumen de la obra de conjunto en un pequeño libro, a modo de prontuario, en el que se actualizaron algunos datos relativos a iglesias que habían sido intervenidas con posterioridad a la publicación de los volúmenes en 2002 (Huerta 2012).

A nuestro juicio, el estudio que se hizo en la Enciclopedia del apartado soriano se sitúa entre los mejores de la misma dedicados al conjunto castellano-leonés, que luego extendió objetivos hacia otras regiones, tarea en la que continúa. Desde el punto de vista que privilegiamos en estas páginas su principal escollo fue una de las apuestas metodológicas de las que se partió, el estudio de lo que de Románico había, quedaba, o se podía documentar, postura que renuncia de antemano a integrar las diferentes fases constructivas de un edificio. No obstante, son numerosos los comentarios de los autores que vinculan orgánicamente fases y estilos, poniéndolos en relación, a pesar de que la obra se realizó con rápidas visitas a los edificios donde frecuentemente se disponía solo de pocas horas para la fase de visu, lo que se suplió con un exhaustivo conocimiento de la bibliografía existente y de las memorias de algunas intervenciones arqueológicas. El trabajo se completó con planimetrías de todos los edificios estudiados, sucintas muchas veces, pero únicas en la mayor parte de los casos, pues no se contaba con plantas, alzados o secciones previas. Estos condicionantes, si cabe, engrandecen más el resultado, al que solo se le puede achacar una visión excesivamente centrada en elementos formales, abordada desde la historia del arte. Otro aspecto que no se debe pasar por alto es la presencia de levantamientos de todos los templos estudiados, lo que supone el siguiente hito, nuevamente, en términos cualitativos y cuantitativos, desde la publicación de la monografía de Gaya Nuño. En la Enciclopedia, se encargaron de las entradas de las iglesias aquí estudiadas los historiadores del arte Juan Manuel Rodríguez Montañés (las parroquias de Nuestra Señora de Campanario: Rodríguez 2002b; San Miguel de Caltojar: Rodríguez 2002c; y la ermita de Santa María de Tiermes: Rodríguez 2002d) y Pedro Luis Huerta Huerta (la parroquial de Calatañazor: Huerta 2002).
Otras publicaciones recientes se limitan al aspecto turístico, o a compilar noticias sumarias de varios centenares de iglesias provinciales, como la de García Gómez, que sigue las conclusiones tradicionales en cuanto a las iglesias estudiadas aquí: Calatañazor, Tiermes, Caltojar, Campanario (García 2012: 120-121, 163-167, 191-193 y 375 respectivamente; García 2004), o a historiar un pueblo (con su iglesia) por parte de esforzados investigadores locales, y en líneas generales sin mayores pretensiones científicas, carentes de novedades de interpretación en lo que nos interesa aquí. Novedoso es un estudio, aunque discutible en sus argumentos y valoración, sobre los restos del Románico civil en la provincia de Soria, pues lista, además de la capitalina Casa de San Blas, el objetivo del artículo, testimonios recientemente destruidos o deslocalizados en Calatañazor, Almazán y Alcozar (Sobrino 2013). Rompen esta tendencia los estudios dedicados a la ermita de San Miguel de Gormaz a raíz de la intervención integral restauradora a que se vio sometido el templo con el descubrimiento de sus pinturas murales románicas (Ávila 2012), el aporte de la intervención arqueológica (Heras, Escribano y Balado 2001) y, sobre todo, el magnífico conjunto de estudios recogidos en un volumen monográfico que resumía todas las intervenciones y estudios practicados al hilo de la restauración de la ermita (Escribano y Heras 2007). Puede afirmarse que la calidad del conocimiento que tenemos ahora de tal ermita supera, por la integración de disciplinas y trabajo interdisciplinar, al que hay de la cercana de San Baudelio, aunque esta lleve un siglo de ventaja de investigación y continuos aportes, individuales casi siempre (desde el estudio de Álvarez y Mélida 1907).

Finalmente, hemos de reseñar, siquiera de pasada, la labor de investigación realizada por el equipo del Proyecto Cultural «Soria Románica», estrechísimamente vinculada a sus intervenciones y a la observación y estudio continuado de los edificios, y que no pudo materializarse en las publicaciones esperadas por la supresión del propio Proyecto $^{10}$. Además de la labor conservadora, restauradora y de rehabilitación de edificios, bienes muebles o entornos, este trabajo ha enriquecido el conocimiento del Románico soriano de manera exponencial, particularmente en lo que a arquitectura se refiere, muchas veces apoyada en otras disciplinas. Particularmente fecunda ha sido la

\footnotetext{
10 Las memorias de las respectivas intervenciones, así como los estudios, análisis... asociados a ellas constan, como es preceptivo desde el punto de vista administrativo, tanto en la Delegación Territorial de Soria de la Junta de Castilla y León, como en la Dirección General de Patrimonio Cultural de la Consejería de Cultura y Turismo de dicha Junta.
} 
arqueología, que ha permitido confirmar las dimensiones de la galería románica original de la iglesia de San Pedro en Caracena, descubrir la singularidad de la de la ermita del Vallejo en Alcozar (en forma de L), y conocer la de la ermita de la Virgen de Lagunas en Villálvaro. En este apartado cabe añadir la novedad de la galería porticada románica de la parroquia de Paones, curioso ejemplar por su configuración y materiales.

En la ermita de la Virgen del Val de Pedro el descubrimiento de un alquerque en la piedra angular del templo (esquina sureste del ábside, bajo cota actual) y la falta completa de ajuar en la necrópolis rechaza la teoría de su origen visigodo (Resino, Delgado y Villanueva 2014); la confirmación de sus dimensiones primeras, por otro lado, permite sospechar que nos hallamos ante un edificio de planta y proporciones similares a la ermita de San Baudelio ${ }^{11}$.

En la iglesia de Santa María de Caracena, interesantísima construcción románica oscurecida por la atención prestada a la célebre galería porticada de la vecina iglesia de San Pedro, la datación de un madero constructivo de la torre (un fragmento de aguja extraído de su zona noroeste, a la altura del coro) ${ }^{12}$ confirma la anterioridad de esta (en realidad, una atalaya musulmana) a la iglesia románica que se adosará posteriormente.

Otro aspecto interesante es el establecimiento de iglesias románicas en loca sacra previos, lo que se confirma observando cómo la cimentación de algunos edificios rompe tumbas previas, como en las parroquias de Aguilera $^{13}$ y Alpanseque ${ }^{14}$, algo documentado ya en otras tierras extremaduranas (Martín 2012: 30). La nómina escasa de iglesias románicas con cabecera recta se ha incrementado con el conocimiento de la que tuvo en un primer momento la parroquia de San Pedro de Mosarejos ${ }^{15}$, y la de la ermita de San Juan en Calatañazor ${ }^{16}$. En cuanto a estructura

\footnotetext{
11 Como advirtió el arquitecto José Francisco Yusta, director de la Oficina Técnica del Proyecto Cultural «Soria Románica», lo que se confirmó por los análisis dimensionales comparativos correspondientes.

12 Análisis radiocarbónico realizado por el Beta Analytic Radiocarbon Dating Laboratory, calibrado mediante el método Sigma 2, que ofrece un 95,4\% de probabilidades de que el hueso extraído de la tumba que cortaba el ábside del templo datase entre los años 880 y 1020 (referencia Beta 308041).

13 Análisis radiocarbónico realizado por el Beta Analytic Radiocarbon Dating Laboratory, calibrado mediante el método Sigma 2, ofrece un 95\% de probabilidades de que el hueso extraído de la tumba que cortaba el ábside del templo datase entre los años 970 y 1040 (referencia Beta 264606).

14 En esta, la tumba parece servir como base a la cimentación del costado norte del templo. Se puede observar en la necrópolis visitable que en dicho lado se habilitó.

15 Según la excavación de Antonio Chaín Galán realizada entre mayo y junio de 2010.

16 Según el seguimiento arqueológico realizado por César Gonzalo Cabrerizo en abril de 2011, con motivo de las obras de desescombro realizadas por la empresa Ruiz Cano.
}

de cubiertas, el avance más interesante lo ha proporcionado la de la ermita de Ntra. Sra. de la Dehesa (Velamazán), compuesta de vigas y pares sobre arcos de diafragma, por su originalidad en tierras orientales de Castilla (Yusta, Santa-Olalla y Lorenzo 2013: 507). Sin duda, la intervención integral sobre la iglesia de San Miguel de San Esteban de Gormaz es la que más conocimiento ha ofrecido, y también sobre la que más exhaustivamente se trabajó en el Proyecto, durante los cinco años que duró (Yusta, Arévalo, Gonzalo, Frías, Santa-Olalla, Ruiz, Borque, Diestro, Sanz y Lorenzo 2013). Especialmente relevantes han sido los datos obtenidos de la intervención arqueológica (el templo se asienta sobre silos musulmanes que amortiza), así como de la retirada minuciosa de revocos hasta rescatar el revestimiento que recubría el templo en toda su extensión al menos en el siglo XII, cuajado de información ofrecida por cientos de grafitos incisos sobre él (Esteras, Gonzalo, Lorenzo, Santa-Olalla, Yusta 2012). Próximas publicaciones alumbrarán sobre este edificio, coetáneo de la ermita de San Baudelio, que contó con una tribuna perimetral que recorría su nave por entero, y con un sistema de puertas y circulaciones que hemos observado en numerosos edificios románicos de la provincia y que están por interpretar.

Para terminar, cabe destacar los «descubrimientos» de los templos románicos de los despoblados de Alconeza, ya arruinado pero en pie, en Tierras de Berlanga (Yusta, Esteras, Gonzalo, Lorenzo y Santa-Olalla 2010), y de Tartajo ${ }^{17}$, todavía inédito, una iglesia románica «entera», enclavada en una finca particular, construida con la técnica de encofrado de cal y canto, de nave única, ábside semicircular cubierto con bóveda de horno y largo presbiterio recto con bóveda apuntada, que hoy es majada de ganado, y tiene cubierta la nave con uralita. Desde la publicación de los tres volúmenes de la Enciclopedia, son las «novedades» arquitectónicas más relevantes que se añaden a la larga nómina provincial.

\section{METODOLOGÍA SEGUIDA PARA EL ESTUDIO DE LAS CUATRO IGLESIAS}

El método de trabajo que siguió la Oficina Técnica del Proyecto Cultural «Soria Románica» (2007-2012) se pensó y diseñó antes de conformar el equipo que habría de constituirla, y se mantuvo durante los cinco

\footnotetext{
A finales del siglo XV Tartajo se despobló, pasando a formar parte del término de Torretartajo (Díez y Galán 2012: 518-519).
} 
años de su existencia. Se constituyó finalmente dicho equipo, dirigido por el arquitecto José Francisco Yusta, y compuesto por nueve profesionales de distintas disciplinas. En la provincia, este método supuso trascender el trabajo prácticamente individual, con intervenciones puntuales, por un método en que participan equipos interdisciplinares de manera estable y coordinada.

Muchas veces se emplea el adjetivo interdisciplinar como talismán en declaraciones programáticas, pero lo cierto es que no se practica demasiado la interdisciplinariedad real. Prueba de ello, entre otras muchas, la escasez de bibliografía firmada por varias personas de disciplinas distintas. Incluso cuánta bibliografía administrativa, informes y memorias, a pesar de estar participadas por profesionales de distintos oficios, suelen formalizarse, siguiendo la metodología empleada, amalgamando estudios y firmas. La parcelación de los saberes, la especialización en la profesión, la ausencia de equipos interdisciplinares estables, y, en fin, la costumbre de trabajar aislados, provoca que apenas se pongan en diálogo conclusiones procedentes de los estudios iconográficos, arqueológicos, históricos y arquitectónicos, más allá de aprovechar este o aquel dato que la bibliografía desgrana. El hecho es que sigue siendo excepcional que especialistas de distintas disciplinas trabajen juntos, condicionante que se ha conseguido vencer en este caso.

Para intervenir en un edificio, objetivo último del equipo que compuso la Oficina Técnica del Proyecto Cultural «Soria Románica» (Yusta, Diestro, Esteras, Gonzalo y Lorenzo 2010; Yusta, Santa-Olalla y Lorenzo 2013), se consideró que había que estudiarlo previamente en profundidad, dado que el propio proceso de intervención desvelaría problemas no planteados antes o perspectivas novedosas en las que profundizar y a las que solo se accede después de un profundo conocimiento del mismo, de su materialidad. Estos estudios incluyeron, en todos los casos, un escrupuloso registro planimétrico nuevo, comparaciones dimensionales, investigación y análisis de la documentación almacenada en archivos, encuesta oral, y puesta en relación del bien en cuestión con el resto del patrimonio cultural conservado desde la más remota antigüedad hasta 1500. Luego, en función del tipo de intervención, se procedió a enriquecerlo con actuaciones arqueológicas, o de restauración-conservación sobre bienes muebles, recreaciones virtuales de estudio, u otro tipo de técnicas especializadas (dendrocronología, radiodatación, estudios geotécnicos, petrológicos, de morteros etc.).
Sobre el conocimiento bibliográfico completo de lo que se ha publicado sobre estas iglesias, y sobre el método de investigación propio que impulsa la Arqueología de Arquitectura, se decidió abordar estos cuatro estudios monográficos que aquí se presentan. Para llegar a las conclusiones a las que se arriba, se han tenido en cuenta, además de la bibliografía previa, exhaustivamente rastreada, memorias de arqueología (Calatañazor, Tiermes), información documental y gráfica de intervenciones anteriores (Calatañazor, Caltojar, Tiermes), la información ofrecida y extractada procedente de la lectura minuciosa de todos los libros de fábrica conservados (en las cuatro iglesias), información oral (Lorenzo 2012b y 2014; en las cuatro también), fotografía histórica procedente de publicaciones y archivos, públicos y particulares (Lorenzo 2012c), e incluso una lectura de paramentos previa que se había realizado en Calatañazor. Particularmente interesante resultó la discusión entre los dos equipos que colaboraron (Proyecto Cultural «Soria Románica» y CSIC) sobre este templo y su controvertido hastial occidental. El Proyecto Cultural «Soria Románica» partía, pues, de una visión territorial del Románico extremadurano, con exhaustivo conocimiento, a partir de estudios propios, del patrimonio románico provincial, y los necesarios vínculos al de las zonas limítrofes. Aunque pudiera parecer paradójico, muchas de sus intervenciones se centraron precisamente en aspectos, bienes u objetos «no románicos», bien porque las necesidades de conservación así lo exigían, o bien, como en este caso, porque del conocimiento preciso de lo que ocurre «después del Románico» pueden ofrecerse datos, inalcanzables con otros métodos, que informan de lo que sucedió «durante».

El Románico soriano se suele definir como «rural» (sobre este tema: Ruiz Montejo 1989; Rodríguez y Garcinuño 2003), consideración que hay que poner en cuarentena cuando se trata de iglesias como las que se estudian en este monográfico, ya que salvo la ermita de Tiermes (perteneciente en su día a la Comunidad de Villa y Tierra de Ayllón, hoy localidad segoviana), el resto son parroquias enclavadas en poblaciones que fueron importantes núcleos demográficos cuando se erigieron (Fig. 5). Así, Caltojar perteneció a la Comunidad de Villa y Tierra de Berlanga (luego, con el proceso señorializador, marquesado de Berlanga), de la que era su aldea más importante todavía en el siglo XIV, y tanto Nuestra Señora de Campanario como Nuestra Señora del Castillo fueron una de las parroquias de sus respectivas villas, Almazán y Calatañazor, es decir, cabezas de Comunidad 


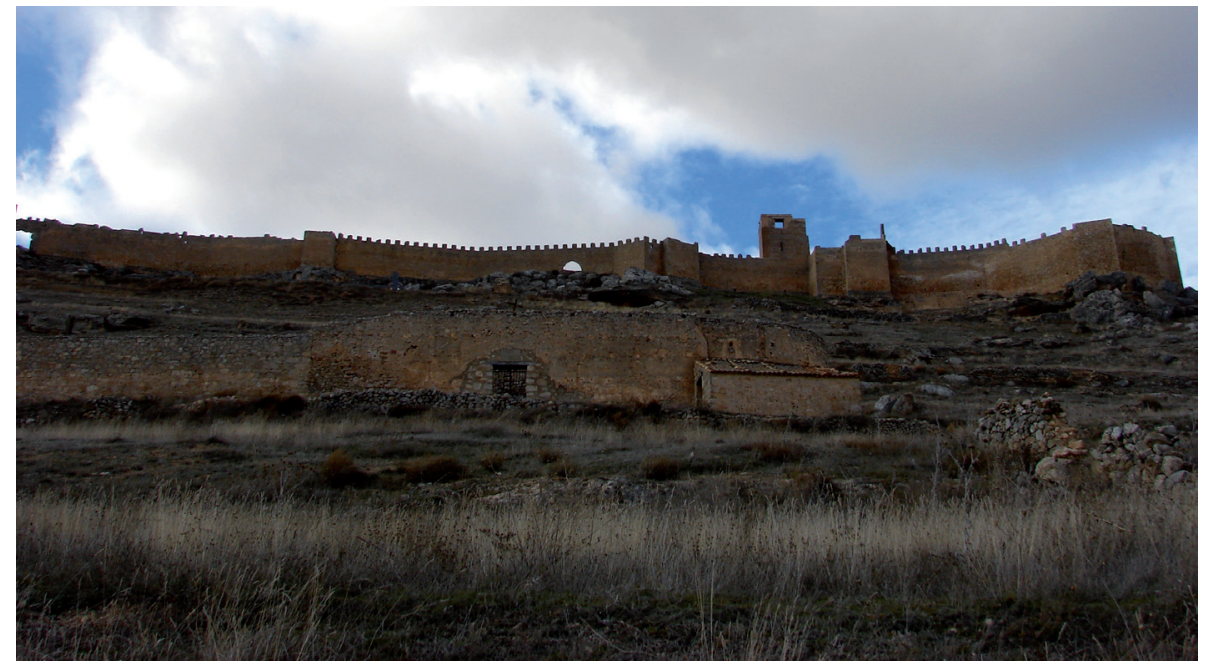

Fig. 5. La villa de Gormaz, hoy casi despoblada, fue cabeza de Comunidad de Villa y Tierra en la Edad Media, y contó con las parroquias de San Miguel, San Juan, Santa María de la Antigua y Santiago, lo que pone en duda los criterios de «ruralidad» que hoy se aplican a ciertas localidades y, por extensión, a sus construcciones románicas. En la imagen, caja de muros de la iglesia románica de San Juan, hoy cementerio, con la fortaleza califal al fondo. Fotografía: Josemi Lorenzo Arribas. de Villa y Tierra. Hablar de "ruralidad" en los siglos XII y XIII en la actual provincia de Soria ha de contraponerse a las zonas netamente urbanizadas, que no pasarían de media docena, entre ellas estas dos últimas, con un puñado de parroquias, collaciones, recinto amurallado, etc. Adolece esta visión aparentemente ruralizada del mundo de antaño de una trasposición simétrica y anacrónica con la situación actual, en que la provincia de Soria es casi un desierto demográfico con respecto a los estándares poblacionales europeos. Pero no se puede hacer la correspondencia sin más con respecto a los siglos centrales de la Edad Media que vieron erigirse estas iglesias. Salvo la ermita termestina, la magnitud y proporciones de las otras tres iglesias para nada presuponen que dieran servicio a población eminentemente rural. De ellas, la que mejor se ha conservado en su traza inicial ha sido la de Caltojar, de tres naves (y con torre románica), configuración tripartita que también compartieron en origen las parroquias de Calatañazor y Almazán.

El patrimonio medieval construido, tal como nos ha llegado, por lo general, no es adscribible a un estilo. Cuando hablamos de «la iglesia románica de...» estamos pensando a través de un paradigma estilístico que fosiliza un edificio en un momento (o momentos) concreto. Después, ese edificio ha tenido su propia evolución que suele quedar minusvalorada, si no directamente obliterada. La propia terminología de la Historia del Arte acusa este imaginario, al sobredimensionar conceptos como «añadidos», «no original», «falso», etc., que dificulta el entendimiento del patrimonio edilicio como un edificio «con historia», orgánico, diacrónico, o en evolución, en pos de criterios más «artísticos» en que, a igualdad de circunstancias, se privilegia lo anterior sobre lo nuevo, igualmente original, no obstante (Fig. 6). En esta provincia, como en general, de los edificios originalmente románicos han interesado a la investigación las partes que conservan de esas épocas, despreciándose el resto.

Es esta la primera vez que se publican lecturas de paramentos de iglesias sorianas, realizadas al calor del mismo impulso y por los mismos equipos, con idéntica metodología de tratamiento. Sus conclusiones, por tanto, establecen un punto de partida que habrá que confirmar o falsar en un futuro, y añaden un nuevo acercamiento al patrimonio construido de origen románico de la Extremadura castellana. Los escrupulosos levantamientos planimétricos realizados fueron material de trabajo tanto para las intervenciones realizadas en los templos al amparo del Proyecto Cultural «Soria Románica» como para las lecturas de paramentos. Hoy son, también documento fehaciente del estado de las fábricas cuando se realizaron.

El Proyecto Cultural «Soria Románica» eligió para la lectura de paramentos estas iglesias por diferentes circunstancias, siempre teniendo en cuenta que no se las consideró aisladamente, sino insertas en un plan que hubo de intervenir, de una manera $u$ otra, sobre otros treinta edificios, como se ha dicho, con necesidades de estudio e intervención muy distintas. Además de los estudios generales ya descritos y aplicados a todos los edificios que competían al Proyecto, solo se intervino arquitectónicamente, en la parroquia de Caltojar, con el fin de frenar el deterioro del óculo del hastial occidental y de la abandonada portada norte, elementos románicos ambos. En la ermita de Tiermes se eliminó vegetación inmediata a la fábrica, que la dañaba y dificultaba el correcto levantamiento. En Calatañazor se intervinieron 


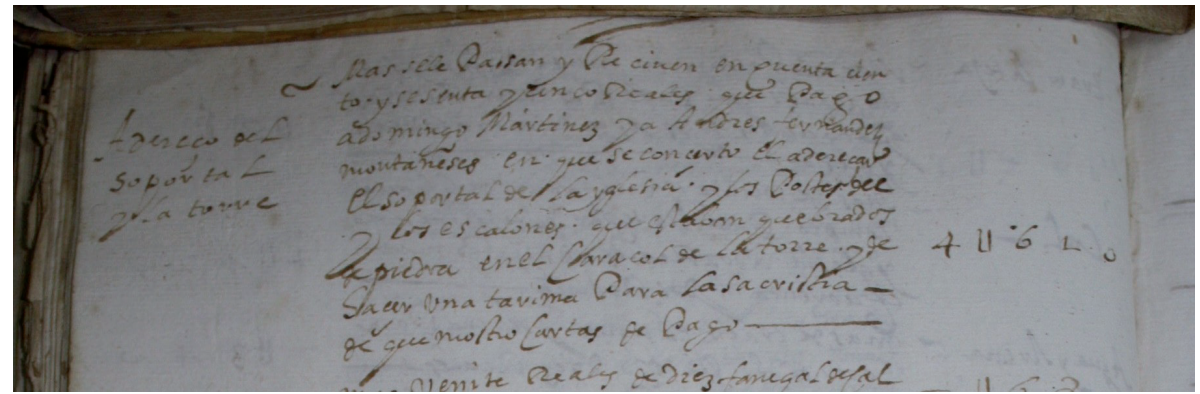

Fig. 6. Referencia documental a arreglos en el «soportal» o pórtico desaparecido de la iglesia de San Miguel Arcángel de Caltojar (1659, noviembre, 25. ADO-S, Libro $100 / 19$, f. $85 \mathrm{v}$ ). numerosos bienes muebles y se hizo un estudio con georradar de todo el interior del templo. Un tratamiento antitermitas se realizó en Campanario (Almazán), además de una intervención instrumental que a continuación se describe.

Del Románico de la villa de Almazán, muy poca bibliografía se había ocupado de Campanario, templo con el que se ceba Madoz (Madoz 1845-1850: sub voce Almazán, 46) y a la sombra siempre de la más favorecida y agradecida iglesia de San Miguel, y lo había hecho confusamente, hasta la publicación de la Enciclopedia. La abundantísima documentación que ofrecían sus libros de fábrica, el desconocimiento cabal de la evolución del templo propendían al estudio sistemático de los acaeceres de su fábrica, y la liberación de las toneladas de palomina en el bajocubierta que realizó el Proyecto Cultural «Soria Románica» en 2007, permitió el acceso a este singular espacio, y particularmente a la cámara abovedada situada sobre el ábside septentrional, por primera vez en tiempos recientes.

En el caso de Calatañazor, localidad bien conocida por su atractivo monumental y por su significación legendaria, la única parroquia actual había sido poco tratada. Lo que había se limitaba en lo fundamental a ciertos rasgos iconográficos de la decoración románica superviviente, pero las profundas remodelaciones acaecidas en el imponente edificio, que «desfiguraron»su imagen medieval, habían desanimado a su estudio. A pesar de ello, intervenciones arqueológicas realizadas en las últimas dos décadas, y el hecho de ser el único caso que contaba con una protolectura de paramentos previa, aconsejaban realizar un estudio de arqueología de la arquitectura en profundidad. A estos estudios hay que sumar el citado estudio geotécnico, que descartó, por ejemplo, algunas creencias transmitidas por vía oral, como la presunta existencia de una cripta bajo la capilla del ángulo sureste del templo.

A pesar de su innegable excepcionalidad por las tres naves románicas, tampoco había un conocimiento preciso de la parroquia de Caltojar, presente sin embargo en toda la bibliografía científica y divulgativa del Románico soriano por la curiosidad de su portada meridional, conformada por arcos de medio punto geminados sin parteluz. La influencia «cisterciense» vía monasterio de Santa María de Huerta que apuntaran hace casi un siglo Taracena y Tudela (1997: 223) se había venido repitiendo sin mayores avances. Se contaba en este caso con la documentación de los proyectos de restauración arquitectónica realizados en las últimas décadas (Cámara y Latorre 1995).

Finalmente, solo la ermita termestina había contado con atención historiográfica continuada, desde el siglo XIX, al calor del yacimiento sobre el cual se erigió y por otro factor de atracción, su presunto visigotismo, teoría a la que se vuelve en la revisión de la guía del yacimiento de 1989 por la aparición de algunos frisos decorados, uno empotrado en la casa del santero y otros en rellenos arqueológicos (Argente, Argente, Casa, Díaz, Domenech, Fernández, González, Izquierdo, Teres, Zozaya, Alonso y Archilla 1989: 70-100), vuelta otra vez a desmentir (Gutiérrez 2003). Para ello se partía de los numerosos estudios que trataban de la decoración escultórica monumental presente en su galería porticada, básicamente centrada en aspectos iconográficos, y de la abundante documentación arqueológica generada por las diversas campañas realizadas en la ciudad celtíbera, romana y visigoda de Tiermes, sistemáticamente excavada desde 1975, y con muchas de sus memorias publicadas, alguna de las cuales ofreció conocimiento válido sobre la ermita románica de Nuestra Señora (Calvo 1913; Casa e Izquierdo 1978, 1979 y 1992; Casa 1979, 1984 y 1992; Casa y Terés 1984a, 1984b, 1984c y 1984d; Casa y Rodríguez 1990). Desgraciadamente, no se conservan datos de la excavación que hiciera Teógenes Ortego en 1969. Es, por tanto, el edificio sobre el que más reflexión arqueológica se ha realizado, interés motivado, no por sí mismo, sino por el excepcional yacimiento en que se encuentra. 


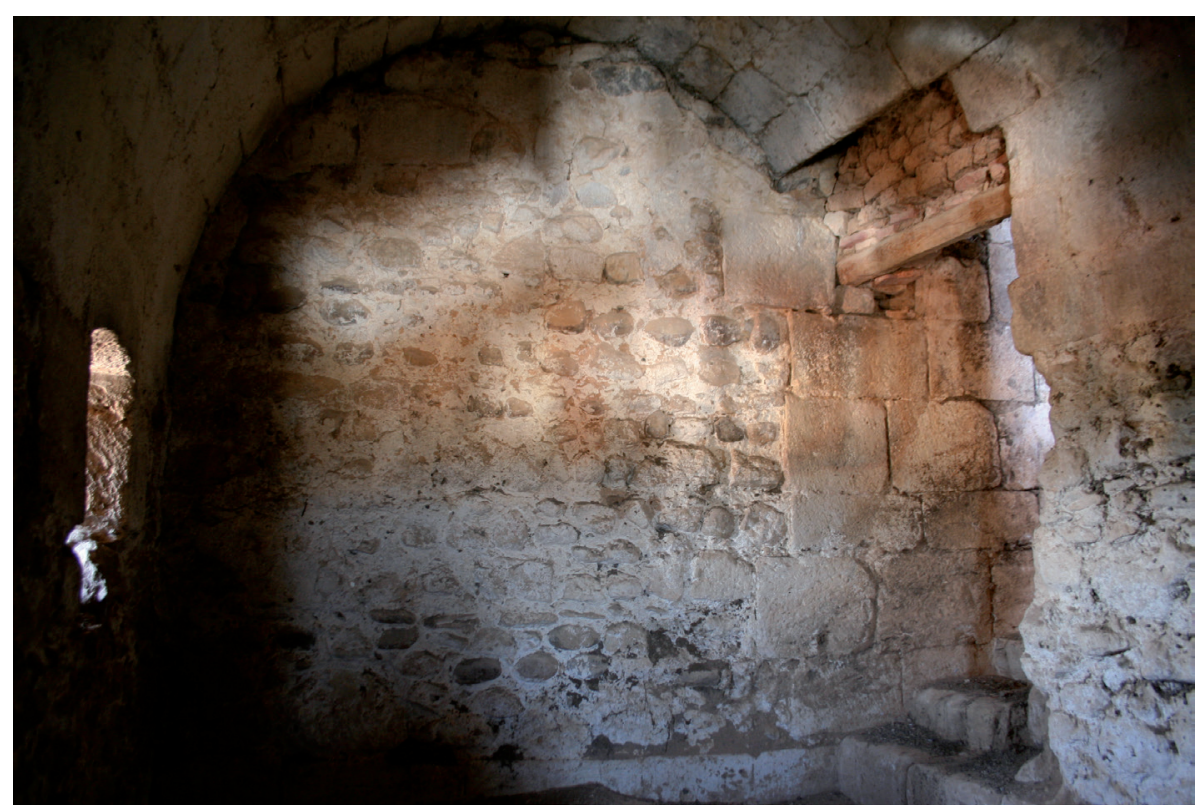

Fig. 7. Ntra. Sra. de Campanario, en Almazán. Acceso desde el interior de la cámara suprabsidal abovedada, situada en el costado norte. Fotografía: José Ángel Esteras Martínez.
Finalmente, la abundante documentación parroquial, conservada en el Archivo Diocesano de Osma-Soria, de estas cuatro iglesias (excepto la ermita termestina, suplida por la información de las numerosas campañas arqueológicas realizadas en torno a ella), y el hecho de haber sido templos que han llegado mayormente a nuestros días sin destrucciones en su fábrica ocasionadas por conflictos bélicos, animaban a una lectura de paramentos. Sobre este último aspecto, se debe destacar que no parece que el paso de los franceses a principios del siglo XIX afectara demasiado a estos templos (sí a otros, o a sus bienes muebles, archivo, ajuar litúrgico...), salvo en el caso de Almazán. En esta localidad sufrieron los libros y parroquia de San Miguel $^{18}$ y es más que probable que también la guerra afectase a Campanario, no a sus libros, pero sí a la fábrica, por las obras que se suceden después de la francesada, como se apunta en el artículo sobre esta iglesia. En Caltojar no se observan daños significativos, por más que sí se destruyó la casa del curato y hasta ase-

\footnotetext{
18 «Se previene que este libro de cuenta es el único que obra en el archivo de esta Parroquia de San Miguel y Santo Domingo, su unida, en razón a que los anteriores fueron incendiados por las tropas francesas con otras alhajas preciosas que tenía, según pormenor resulta del testimonio dado por tres notarios en el día 21 de marzo de 1815, que se halla al principio del libro de bautizados que rige sin que resulte cantidad alguna de alcance en favor de esta parroquia, pues aunque el mayordomo Manuel Angulo, antecesor a Antonio Gil le estaba debiendo 300 y tantos reales, no tuvo efecto su pago, mediante haberle incendiado su casa con cuantos bienes y efectos tenía, quedando reducido a la mayor miseria y precisado a vivir de limosna en casa de un hermano político, hasta que falleció» (Archivo Parroquial de Almazán. Libro de Cuentas de la parroquia de San Miguel (1808-1838), Libro 16, s.f. r, [sin fecha]).
}

sinaron al propio párroco ${ }^{19}$. En Calatañazor se protegió la parroquia ${ }^{20}$. Por el despoblado donde se asienta la ermita de Tiermes no parece que afectara la francesada, aunque sí al vecino pueblo de Pedro ${ }^{21}$.

Los resultados de la aplicación de la arqueología de la arquitectura que se siguen a continuación confirman o desmienten ciertas hipótesis sobre los edificios estudiados. Pero, más allá de ello, muestran la profundidad en el abordaje de estas fábricas. Los artículos resumen las correspondientes memorias presentadas a la Dirección General de Patrimonio de la Junta de Castilla y León, que las encargó a través del Proyecto Cultural «Soria Románica». El minucioso estudio del despiece de los edificios en cada uno de sus elementos, y el posterior ensamblaje de datos, unidades estratigráficas, actividades y etapas queda ahí recogido para quien lo quiera consultar. Destaco, para finalizar, las aportaciones que considero más novedosas a que se llega en cada edificio, comenzando por los dos más grandes en tamaño y complejidad

\footnotetext{
19 «2.000 reales que ha pagado al concejo de Matamala [de Almazán] por la madera que dieron para la edificación de la casa de esta iglesia que quemaron los franceses el día 5 de enero del año de 1811, después de dar la muerte al señor cura don Cecilio Berlarguer a las puertas de la iglesia a la violencia de los fusiles» (Archivo Diocesano de Osma-Soria (ADO-S), Libro 100/22, f. 13r. 1818, mayo, 25).

$20 \ll 6.000$ reales de vellón que se le prometieron y gratificaron al capitán de guardia cuando en el 21 de noviembre de 1808 se acampó en esta villa y sus confines la tropa francesa porque puso guardia en la puerta de la iglesia para que no fuese saqueada como otras lo fueron» (ADO-S, Libro 96/39, s.f. 1810, octubre, 2).

21 Donde sufrió la casa del curato un destrozo «causado por el incendio hecho por los franceses» (Archivo Diocesano de Sigüenza, Sección Civil, 1816-02, doc. 7, escrito en 1816).
} 


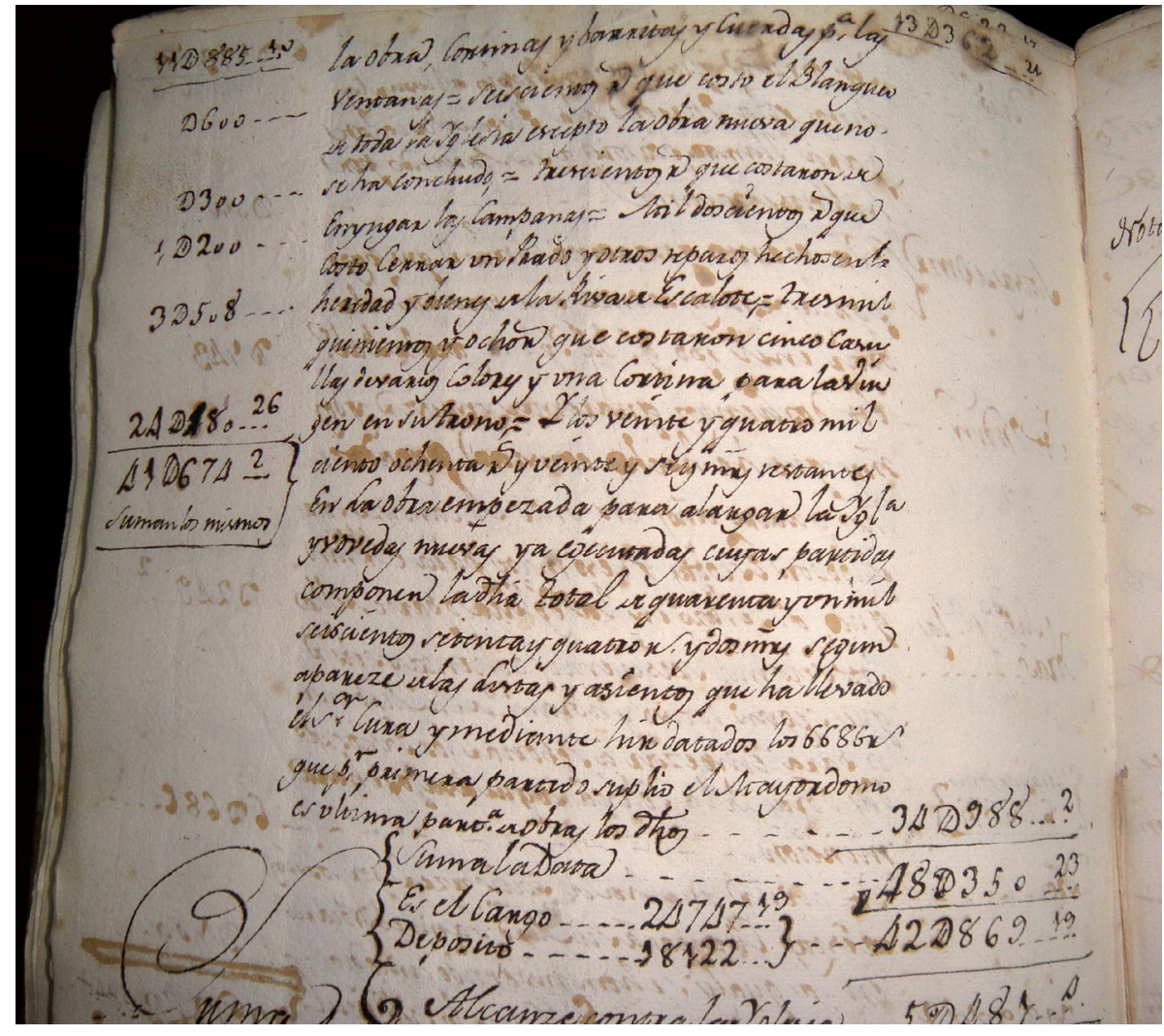

Fig. 8. Asiento documental de 25 de noviembre de 1799 procedente de la parroquia de Ntra. Sra. de Campanario, en Almazán, donde se documentan, entre otros gastos, «24.280 reales y 26 mrs restantes en la obra empezada para alargar la iglesia y bóvedas nuevas ya ejecutadas» (ADO-S, Libro 38/35, s.f., v). evolutiva, que además son los que menos interés han despertado historiográficamente desde el punto de vista del estudio del Románico. Ambos suponen un estimulante reto para cualquier equipo de investigadores.

Sobre la iglesia de Nuestra Señora de Campanario, en Almazán, las conclusiones reivindican la «autenticidad románica» de elementos sobresalientes conservados aquí, y que en otros sitios no han llegado a nuestros días. Tres de las nueve etapas constructivas diferenciadas son románicas. En aquellas se configura la cabecera tripartita, el transepto (con el husillo para la escalera de caracol) cuya bóveda se ha venido considerando gótica y aquí se establece su carácter románico, la cámara suprabsidal (Fig. 7) y el primer tramo de la nave, que aunque se pensó abovedada se cerró con cubierta de madera. Será la gran actuación de finales del siglo XVIII la que sustituya la cubierta de madera del templo por bóvedas (Fig. 8), a la vez que eleva el campanario del que toma su advocación. Finalmente, en el siglo siguiente se reformula el cimborrio sobre el crucero, elemento que el análisis estratigráfico secuencia en este punto, a pesar de su tipología (pero no cronología) gótica.

El establecimiento de las secuencias constructivas de la iglesia de Nuestra Señora del Castillo de Calatañazor descubre, como novedad, parte del muro norte de la nave como originario (junto a partes del occidental y meridional) y una configuración de tres naves (otra iglesia más, poco «rural», a añadir a la lista, en un población que, efectivamente, fue villa), y un edificio, hasta hoy desconocido, adosado al sur del templo, sobre el que se asienta la capilla lateral visible hoy. La interpretación secuencial del hastial occidental (Figs. 9 y 10), quizá la parte más compleja y a la vez visible del templo, se resuelve, no sin razonables dudas, en esta lectura asociando el elemento que se ha venido entendiendo, también con cautelas, como probable resto de una torre defensiva anterior o una posible «espadaña prerrománica» fosilizada en el muro actual como, en realidad, un estribo de la torre de campanas, realizado de forma curva para salvar el buzamiento del terreno, y por tanto contemporáneo a ella (siglo XVII). La dificultad de este edificio, que enmascara otros a su vez, sitúa a la Arqueología de la Arquitectura como el método más capaz, de los que actualmente se aplican, para abordarlo e interpretarlo diacrónicamente.

En Caltojar se concluye que, a pesar de sus tres naves, la central se pensó en origen en que fuera rematada con cubierta de madera, y no por una bóveda. No llegaría esta hasta 1713, y medio siglo después las laterales. Como en Campanario, es el siglo XVIII el que dota de bóvedas a iglesias, románicas en origen, que se cubrieron con madera en la época de su construcción. 


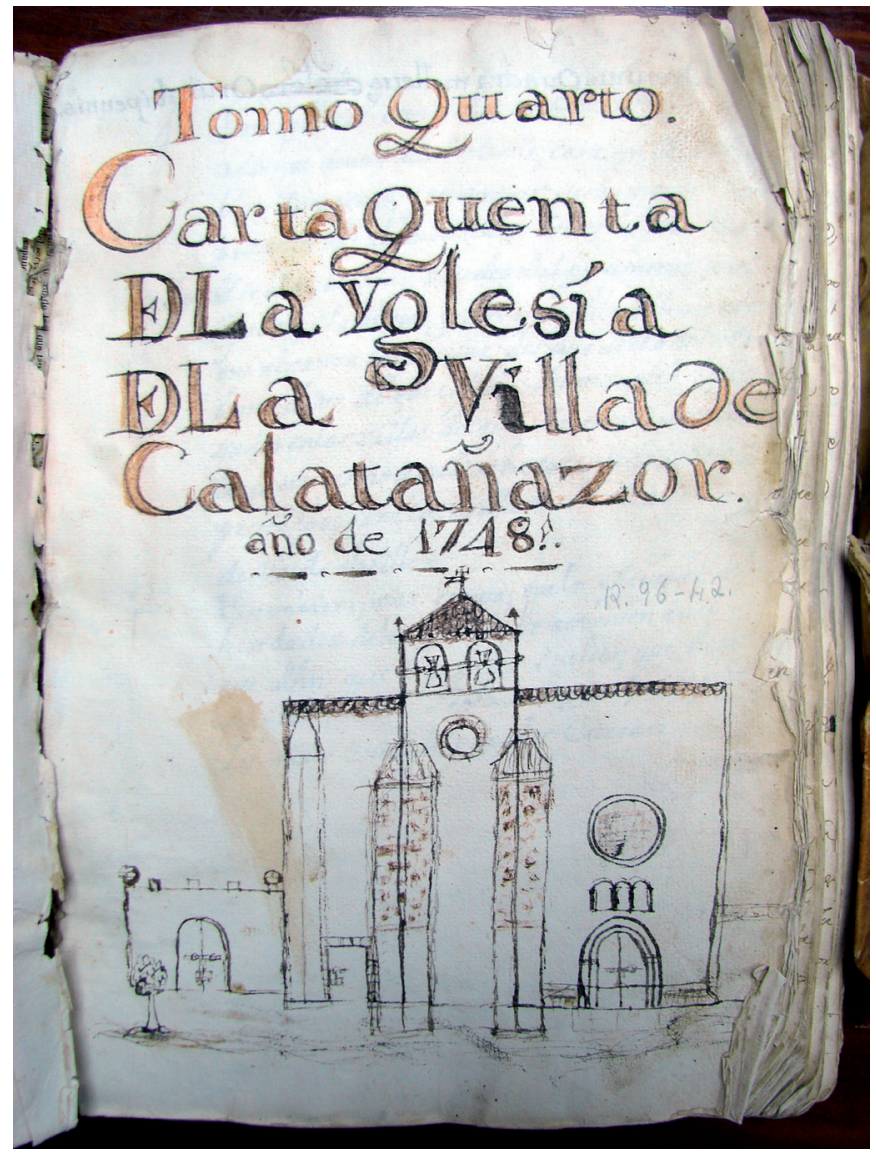

Fig. 9. Frontispicio de uno de los libros de fábrica (o carta-cuenta) de la parroquia de Ntra. Sra. del Castillo de Calatañazor, donde una mano dibujó el alzado occidental del templo en 1748 (ADO-S 96/42).

No son, por tanto, bóvedas románicas ni góticas por cronología, como se pensaba hasta ahora. Del mismo modo, la estancia norte no es del siglo XVII, sino que hay que retrotraerla a finales del siglo XV. Esta iglesia tuvo un pórtico meridional, del que nada ha llegado, $\mathrm{y}$ del que desconocemos su morfología.

La lectura de paramentos de la ermita de Tiermes confirma que no hay argumentos estratigráficos para defender el recurrente argumento de la existencia de un edificio previo, que cierta historiografía hacía romano o visigodo (Fig. 11). La huella de las columnillas que se adosaron a los muros interiores de la nave, articulándola pero sin función estructural, permiten afirmar que se hicieron en fase románica. La célebre galería porticada que hoy vemos sustituye a otra anterior, no muy lejana en el tiempo, pudiendo corresponder la nueva al siglo XIII. Del XVI será la parte inferior de la estancia norte y la espadaña, y del XIX la elevación de la segunda planta del primero.

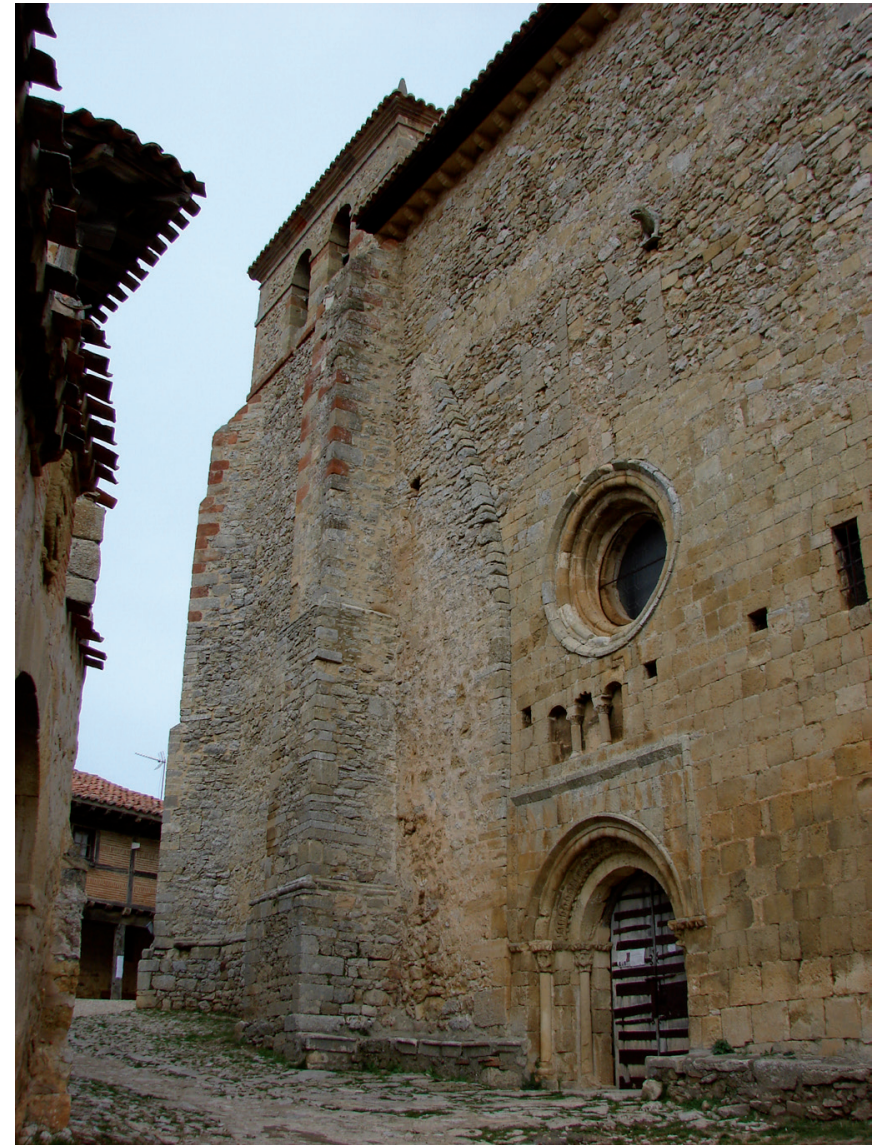

Fig. 10. Iglesia de Ntra. Sra. del Castillo de Calatañazor. Vista del complejo hastial occidental. Fotografía: Josemi Lorenzo Arribas.

En conclusión, desde un punto de vista metodológico el estudio del Románico en la provincia de Soria, como en general, ha consistido en meritorios esfuerzos individuales de investigadores, a veces casi épicos, que a lo sumo contaron con el consejo y cercanía de otros colegas de profesión, pero trabajaron solos. Circunstancias favorables han posibilitado que un amplio equipo de trabajo haya podido alterar esta tendencia, y queda a juicio del lector evaluar si este salto cualitativo ha merecido o no la pena. Desde un punto de vista historiográfico, la mayor parte de las iglesias románicas que esmaltan la provincia de Soria carece de estudios arquitectónicos rigurosos, hecha la salvedad de las descripciones de los volúmenes de la Enciclopedia del Románico y de las que tratara Gaya Nuño, con las limitaciones apuntadas. Casi siempre se ha pretendido inferir información sobre las fábricas de los templos a partir de su escultura monumental o rasgos decorativos. Excluidas las iglesias de la capital y las antedichas al comienzo de estas páginas, tan solo las iglesias de San Esteban de Gormaz y la ermita de Tiermes parecen haber contado con atención permanente. Apenas se cuentan ejemplos de trabajos interdisciplinares, panorama 


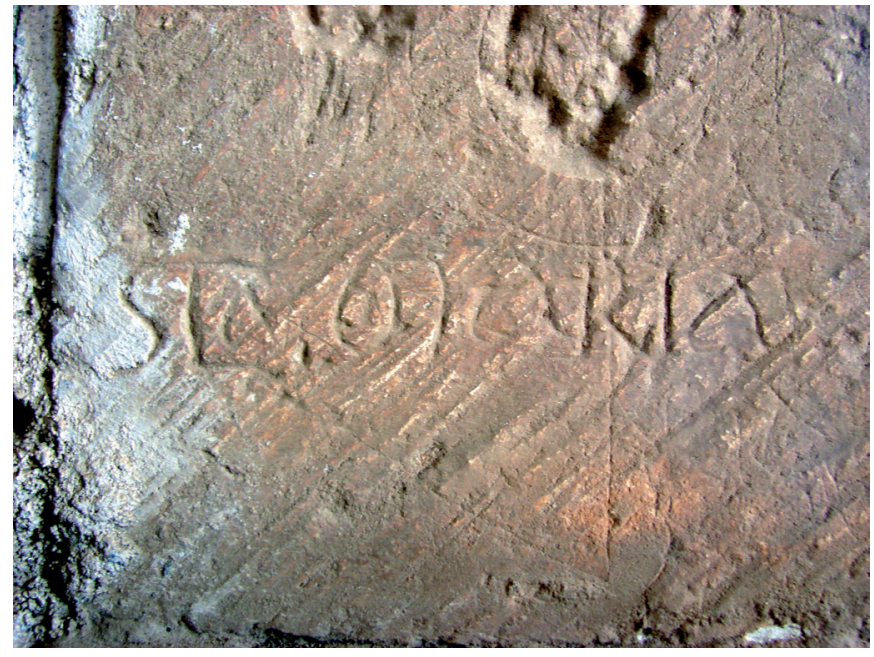

Fig. 11. Ermita de Santa María en Montejo de Tiermes. Inscripción en letras góticas con la advocación del templo: SanCtA MARIA en el intradós del salmer oriental del arco de la portada de ingreso. Fotografía: Josemi Lorenzo Arribas.

del que se exceptúa el mentado trabajo colectivo sobre la ermita de San Miguel de Gormaz, convenientemente publicado (Escribano y Heras 2007), y que debiera ser un espejo metodológico donde mirarse otras intervenciones y publicaciones posteriores.

La aplicación de la Arqueología de la Arquitectura a los cuatro templos seleccionados trasciende el hecho obvio de que ahora conozcamos mejor que antes estos edificios singulares. Su construcción, y aun su evolución, se imbrican en un sistema orgánico que solo tiene sentido analizado desde una perspectiva territorial que, obvia decirlo, trasciende la actual división provincial. La interdisciplinariedad desde la cual se los ha abordado y la novedad de la aplicación de la metodología de la lectura de paramentos, realizada contando con una gran cantidad de documentación de variado tipo que se ha integrado en el análisis, trasciende la idea de los edificios considerados como «monumento artístico» y aun la de testigos materiales que los hace susceptibles de tratamiento arqueológico. Su análisis minucioso y detenido los convierte también en indicadores de los recursos de las sociedades que los hicieron y transformaron, haciendo de sus fábricas testimonio siempre original en su devenir diacrónico.

En cierto modo, se supera, con estos cuatro ejemplos, el tradicional tratamiento de la arquitectura románica provincial como repositorio descriptivo de elementos formales aislados que revelan ese estilo. Es más, entender la fase o fases románicas exige muchas veces analizar elementos posteriores (materiales, documentales...) que informan de sí mismos, pero también retrospectivamente. Dicho esto, la actitud fundamental con la que entendemos que ha de abordarse este patrimonio ha de considerar el edificio como proceso histórico, vivo por tanto e inacabado, y no como fósil que dejó huellas originales maltratadas por una evolución histórica que hay que deconstruir analíticamente para llegar a unas conclusiones que «rescaten» un estilo u otro. En esencia, explicar un edificio es dar cuenta de dicho proceso.

\section{Nota: Criterios de transcripción de los Apéndices documentales}

Al final de cada uno de los artículos que siguen se incluye un Apéndice documental que resume algunos de los asientos más significativos con información arquitectónica. Se extraen de los gastos («descargo»o «data») registrados en los libros de fábrica de las respectivas iglesias.

Los documentos se presentan por orden cronológico, y fechan el momento del apunte. Hay que tener en cuenta que los mayordomos suelen hacer las cuentas de lo gastado con cargo a la fábrica de la iglesia cada dos años más o menos, con lo que los asientos de gasto corresponden a obras realizadas en los años inmediatamente antecedentes o en el propio año en que se recogen las cuentas. El margen de error va desde la fecha de las últimas cuentas consignadas a la que recoge el asiento que interesa. Se recoge la data tópica solo cuando el lugar de firma difiere de la localidad donde se emplaza el templo. A continuación, entre paréntesis, figura la signatura archivística del libro consultado. Salvo pocas excepciones, estos se custodian en el Archivo Diocesano de Osma-Soria, sito en El Burgo de Osma. El primer número corresponde a la localidad (que el Archivo indexa por orden alfabético), se sigue de una barra (/), y un segundo guarismo, que se refiere al número de libro de los conservados de esa iglesia. Comienza siempre la serie por los libros sacramentales, y continúa por los de administración, entre los que se encuentran los de fábrica. Finalmente, la foliación (o paginación) de donde se extraen los datos. Si el libro no está foliado se expresa si el asiento documental se encuentra en el recto o vuelto del folio o folios.

La transcripción recoge el tenor literal, pero modernizando y actualizando la grafía, signos diacríticos y acentuación. Se desarrollan las abreviaturas. Las cantidades, en el original tradicionalmente escritas en letra, se expresan en guarismos para facilitar la lectura. 
Ha de tenerse en cuenta que el fin último de este trabajo fue instrumental, propedéutico para la intervención en los edificios, y por ello se presentó de la manera más accesible posible para facilitar la consulta y discusión de profesionales no acostumbrados a traslados de tipo más paleográfico.

En la documentación que produjo el Proyecto Cultural «Soria Románica» figuran las memorias por extenso, con las transcripciones completas y con las fotografías adjuntas de los folios de los que se extrajo información. Allí difiere el modo de presentación, más elaborada, pero el espacio disponible y la función de Apéndice que aquí cumple, aconsejaron su simplificación. Esta documentación se consultó entre los años 2008 y 2010.

\section{Referencias administrativas / agradecimientos}

El Proyecto Cultural «Soria Románica» es un plan de conservación, difusión y divulgación del Románico de la provincia de Soria. La Oficina Técnica que se formó al efecto trabajó entre 2007 y 2012. La Junta de Castilla y León promovió y financió este Proyecto, gestionado por la Fundación Duques de Soria con la colaboración del Obispado de Osma-Soria, desde el que se encargaron estas cuatro lecturas de paramentos que este artículo presenta. La historiadora Blanca Bazaco Palacios y el historiador Marino Real Gallego colaboraron, en el marco del Proyecto Cultural «Soria Románica», en la transcripción de parte de la documentación de las parroquias de Campanario (Almazán) y Caltojar.

\section{Ficha técnica de la Oficina Técnica del Proyecto Cultural «Soria Románica»}

José Francisco Yusta (arquitecto y Director de la Oficina Técnica). José Ángel Esteras e Inés Santa-Olalla (arquitectos). José Manuel Borque (aparejador). César Gonzalo (arqueólogo). Francisca Diestro (restauradora). Josemi Lorenzo (historiador y documentalista). Carmen Frías (gestora cultural). Luis Miguel Sanz (infógrafo y delineante). Concepción Ruiz (delineante).

\section{Fuentes primarias}

Cabré Aguiló, J. 1916: Catálogo Monumental de la provincia de Soria. 8 tomos. Manuscrito inédito, consultable en línea: http://biblioteca. cchs.csic.es/digitalizacion_tnt/index interior_soria.html [consultado el 16/09/2014].

Cámara, L. y Latorre, P. 1990: Proyecto de restauración de la iglesia parroquial de Caltojar. (Soria). Informe manuscrito, Archivo Central de la Junta de Castilla y León. Caja 4481. Subcarpeta: Proyecto.
Martínez Tercero, E. 1981: Proyecto de Restauración de la Iglesia Parroquial de San Miguel Arcángel. Informe manuscrito, Archivo Central de la Junta de Castilla y León. Caja 4481. Subcarpeta: Documentación Administrativa.

Sáinz Magaña, M. E. 1984a: El románico soriano. Estudio simbólico de los monumentos, tesis doctoral, 2 vols. Universidad Complutense, Facultad de Geografía e Historia.

\section{Bibliografía}

Álvarez, M. A. y Mélida, J. R. 1907: “Un monumento desconocido. La ermita de San Baudelio en término de Casillas de Berlanga (provincia de Soria)", Boletín de la Sociedad Española de Excursiones, 15, pp. 144-155.

Álvarez Terán, C. y González Tejerina, M. 1934-1935: "Las iglesias románicas de San Esteban de Gormaz", Boletín del Seminario de Estudios de Arte y Arqueología, 3, pp. 299-330.

Amo Ramírez, J. del y Frías Balsa, J. V. de 1995: "La ermita de Nuestra Señora del Vallejo, hoy iglesia parroquial de Alcozar”, Celtiberia, 89, pp. 377-399.

Arco y Garay, R. del 1932: El arte románico en la región pirenaica especialmente en Aragón. Impr. Gambón, Zaragoza.

Arco y Garay, R. del 1942: Catálogo monumental. Huesca. CSIC, Madrid.

Argente Oliver, J. L., Argente Oliver, I., Casa Martínez, Carlos de la, Díaz Díaz, A., Domenech Esteban, M., Fernández Martínez, V., González Uceda, A., Izquierdo Bertiz, J. M., Teres Navarro, E., Zozaya Stabel-Hanssen, J., Alonso Lubias, A. y Archilla, R. 1989: Tiermes. Guía del yacimiento arqueológico. Junta de Castilla y León, Soria.

Artigas y Corominas, P. 1932: "Por tierras de gesta. San Esteban de Gormaz. III. Idea de sus monumentos y de sus principales fundaciones", Boletín de la Sociedad Española de Excursiones, 40/3, pp. 221-235.

Ávila Juárez, A. de 2012: "Las pinturas románicas de San Miguel de Gormaz: una aproximación a su iconografía”, Cuadernos de arte e iconografía, 21/42, pp. 205-259.

Bango Torviso, I. G. 1975: “Atrio y pórtico en el románico español: concepto y finalidad cívico-litúrgica”, Boletín del Seminario de Estudios de Arte y Arqueología, 40-41, pp. 175-188.

Bango Torviso, I. G. 1997: El arte románico en Castilla y León. Banco de Santander, Madrid.

Barrio Onrubia, R., Lerín Sanz, M., Tarancón Gómez, M. a J., Ruiz de Marco, A. y Arellano Hernández, Ó. L. 1991: "El Monasterio de San Vicente de Alcozar (Soria): aproximación arqueológica en base a su realidad histórica", Numantia. Arqueología en Castilla y León, 5, pp. 167-179.

Calvo, I. 1913: “Termes, ciudad celtíbero-arévaca", Boletín de la Real Academia de la Historia, 29, pp. 384-387.

Cámara, L. y Latorre, P. 1995: "Iglesia Parroquial de San Miguel Arcángel. Caltojar (Soria)", en Castilla y León Restaura, 174-175. Junta de Castilla y León, Valladolid.

Casa Martínez, C. de la 1979: "Los monasterios de San Salvador y Santa María de Tiermes: la documentación y los datos arqueológicos", Revista de Archivos, Bibliotecas y Museos, 82, 3, pp. 525-529.

Casa Martínez, C. de la 1984: "Las necrópolis medievales de Tiermes: Sistemas de enterramiento", en Actas del I Symposium de Arqueología Soriana, pp. 499-510. Servicio de Investigaciones Arqueológicas Diputación Provincial, Soria.

Casa Martínez, C. de la 1992: Las necrópolis medievales de Soria. Junta de Castilla y León, Diputación Provincial Asociación Española de Arqueología Medieval, [Valladolid] Soria [Madrid].

Casa Martínez, C. de la e Izquierdo Bértiz, J. M. 1978: "Excavaciones en la Ermita Románica de Nuestra Señora de Tiermes. Montejo de Tiermes (Soria). Campaña de 1977”, Celtiberia, 28, 55, pp. 61-63.

Casa Martínez, C. de la e Izquierdo Bértiz, J. M. 1979: "Excavaciones en la necrópolis medieval de Tiermes. Campaña de 1978”, Celtiberia, 29, 57, pp. 19-33.

Casa Martínez, C. de la e Izquierdo Bértiz, J. M. 1992: “Aproximación al hábitat visigodo de Tiermes", en Actas II Symposium de Arqueología Soriana, Homenaje a D. Teógenes Ortego y Frías, 19-21 de octubre de 1989, tomo 2, pp. 1.007-1.019. Diputación de Soria, Soria. 
Casa Martínez, C. de la y Rodríguez Adrados, J.-V.1990: "Cartelas medievales de Tiermes (Soria)", en El Románico en Silos. IX Centenario de la consagración de la iglesia y claustro. 1088-1988, pp. 559-563. Abadía de Silos, Burgos.

Casa Martínez, C. de la y Terés Navarro, E. 1984a: "Excavaciones arqueológicas en el yacimiento medieval de Tiermes. Campañas 1979-1980”, en J. L. Argente Oliver (dir.), Tiermes II. Campañas de 1979 y 1980. Excavaciones realizadas en la Ciudad Romana y en la Necrópolis Medieval, pp. $322-$ 325. Ministerio de Cultura, Dirección General de Bellas Artes, Madrid.

Casa Martínez, C. de la y Terés Navarro, E. 1984b: "Trabajos en el interior de la ermita", en J. L. Argente Oliver (dir.), Tiermes II. Campañas de 1979 y 1980. Excavaciones realizadas en la Ciudad Romana y en la Necrópolis Medieval, pp. 328-333. Ministerio de Cultura, Dirección General de Bellas Artes, Madrid.

Casa Martínez, C. de la y Terés Navarro, E. 1984c: "Excavaciones arqueológicas en la ermita románica de Nuestra Señora de Tiermes” en J. L. Argente Oliver (dir.), Tiermes II. Campañas de 1979 y 1980. Excavaciones realizadas en la Ciudad Romana y en la Necrópolis Medieval, pp. 336349. Ministerio de Cultura, Dirección General de Bellas Artes, Madrid.

Casa Martínez, C. de la y Terés Navarro, E. 1984d: "Excavaciones arqueológicas en la necrópolis medieval de Tiermes”, en J. L. Argente Oliver (dir.), Tiermes II. Campañas de 1979 y 1980. Excavaciones realizadas en la Ciudad Romana y en la Necrópolis Medieval, pp. 351-416. Ministerio de Cultura, Dirección General de Bellas Artes, Madrid.

Cerralbo, Marqués de 1908: Discursos leidos ante la Real Academia de la Historia. En la recepción pública del Enrique de Aguilera y Gamboa, marqués de Cerralbo en 31 de Mayo de 1908. Sucesores de Rivadeneyra, Madrid.

Cortés Arrese, M. Á. 1988: "Teógenes Ortego y el románico soriano", Celtiberia, 38, 75 'In memoriam Teógenes Ortego y Frías', pp. 87-94.

Diestro, F. y Lorenzo, J. 2010: "Restauración, devoción, documentación. Vírgenes con Niño medievales de la provincia de Soria", Ge-conservación. Publicación digital hispano-lusa de conservación y restauración, 1, pp. 163-181, [en línea] <http://ge-iic.com/ojs/index.php/revista/article/ view/18> [consultado el 17/09/2014].

Díez Sanz, E. y Galán Tendero, V. M. 2012: Historia de los despoblados de la Castilla oriental (Tierra de Soria, siglos XII al XIX). Diputación Provincial, Soria.

Enríquez de Salamanca, C. 1986: Rutas del Románico en la provincia de Soria. Cayetano Enríquez de Salamanca y Navarro, Madrid.

Escribano Velasco, C. y Heras Fernández, E. (coords.) 2007: San Miguel de Gormaz. Plan integral para la recuperación de un edificio histórico. Junta de Castilla y León, Valladolid.

Esteras, J.Á., Gonzalo, C., Lorenzo, J., Santa-Olalla, I. y Yusta, J. F. 2012: "La piel que habla. Grafitos de los siglos XI-XIII sobre el revoco románico de la iglesia de San Miguel de San Esteban de Gormaz (Soria)", en P. Ozcáriz (ed.), La memoria en la piedra. Estudios sobre grafitos históricos, pp. 88-107. Servicio de Publicaciones del Gobierno de Navarra, Pamplona.

García Gómez, F. J. 2004: "El Románico en Soria. Arte y patrimonio", Revista de Soria, 47, pp. 3-30.

García Gómez, F. J. 2007: "Pilas bautismales románicas en la provincia de Soria”, Celtiberia, 57, 101, pp. 315-358.

García Gómez, F. J. 2012: Románico soriano. Arte y patrimonio. Universidad Europea Miguel de Cervantes, Valladolid.

Garnelo, J. 1924: "Descripción de las pinturas murales que decoran la ermita de San Baudelio en Casillas de Berlanga (Soria)", Boletín de la Sociedad Española de Excursiones, 32, pp. 1-14.

Gaya Nuño, J. A. 1946: El Románico en la provincia de Soria. Edición facsímil de 2003. CSIC, Madrid.

Gaya Nuño, J. A. 1962: Teoría del Románico. Publicaciones Españolas, Madrid.

Gómez-Moreno, M. 1923: "L'entrecroisement des arcades dans l'architecture árabe", en Actes du Congrés d'Histoire de l'Art (1921), tomo 1, pp. 318330. Presses Universitaires de France, Paris.

Gómez-Moreno, M. 1925: Catálogo monumental de España. Provincia de León (1906-1908), 2 vols. Ministerio de Instrucción Pública y Bellas Artes, Madrid.
Gómez-Moreno, M. 1927: Catálogo monumental de España. Provincia de Zamora (1903-1905), 2 vols. Ministerio de Instrucción Pública y Bellas Artes, Madrid.

González Cabrerizo, E. 1929: Biografia del insigne soriano San Martín de Finojosa, Abad de Huerta y Obispo de Sigüenza. Sociedad Económica Numantina de Amigos del País, Soria.

Gonzalo, C., Esteras, J. Á. y Lorenzo, J. 2009: "Claustros y galerías porticadas en el Románico de Soria”, en Paisaje interior. Las Edades del Hombre. Soria, concatedral de San Pedro, mayo a diciembre de 2009, pp. 125-162. Gráficas Varona, [s.1.].

Gudiol Ricart J. y Gaya Nuño, J. A. 1948: Arquitectura y escultura románicas. Ars Hispaniae, vol. 5. Editorial Plus-Ultra, Madrid.

Gutiérrez Dohijo, E. 2003: "Puntualizaciones sobre la hipótesis de un edificio visigodo alrededor de la ermita de Nuestra Señora de Tiermes (Montejo de Tiermes, Soria)", en L. A. García Moreno, C. Bosch Jiménez, L.A. García Moreno, M. ${ }^{a}$ E.Gil Egea y M. Vallejo Girvés (coords.), Santos, obispos y reliquias, Acta Antiqua Complutensia, vol. 3, pp. 173-192. Universidad de Alcalá, Alcalá de Henares.

Heras, E., Escribano, C. y Balado, A. 2001: "San Miguel de Gormaz (Soria). Estudio y puesta en valor de un edificio histórico", en Actas del V Congreso de arqueología medieval española (Valladolid, 22 a 27 de marzo de 1999), pp. 393-405. Junta de Castilla y León, Valladolid.

Hernández Álvaro, A. R. 1984: La imaginería medieval en la provincia de Soria. Centro de Estudios Sorianos, Soria.

Hernando Garrido, J. L., Huerta Huerta, P. L., Nuño González, J. y Rodríguez Montañés, J. M. 2001: El arte románico en la ciudad de Soria. Fundación Santa María la Real, Aguilar de Campoo.

Huerta Huerta, P. L. 2002: "Calatañazor. Iglesia de Santa María del Castillo", en García Guinea, M. Á. y Pérez González, J. M. (dirs.), Enciclopedia del Románico en Castilla y León. Soria, vol. I, pp. 284-288. Fundación Santa María la Real, Aguilar de Campoo.

Huerta Huerta, P. L. 2012: Todo el Románico de Soria. Fundación Santa María la Real, Aguilar de Campoo.

Huerta Huerta, P. L., Rodríguez Montañés, J. M., Nuño González, J., Hernando Garrido, J. L., Echeverría Echepare, J. M. y Aragón Ruiz, I. 2002: Soria, 3 vols., en García Guinea, M. Á. y Pérez González, J. M. (dirs.), Enciclopedia del Románico en Castilla y León. Fundación Santa María la Real, Aguilar de Campoo.

Izquierdo Bértiz, J. M. 1985: “Arte románico”, en J. A. Pérez Rioja (dir.), Historia de Soria, tomo 2, pp. 263-296. Centro de Estudios Sorianos, Soria.

Izquierdo Bértiz, J. M. 1990: "El relieve de los profetas de Barca en el marco de la influencia silense en la provincia de Soria", en El románico en Silos. IX centenario de la consagración de la iglesia y claustro, 1088-1988, pp. 553-555. Abadía de Silos, Burgos.

King, G. G. 1923: "Algunos rasgos del influjo oriental en la arquitectura española de la Edad Media”, Arquitectura. Órgano de la Sociedad Central de Arquitectos, 48, pp. 85-92.

King, G. G. 1925: "The problema of the Duero", Ars Studies. Medieval, Renaissance and Modern, 3, pp. 3-11.

La ciudad 1997: La ciudad de seis pisos. Las Edades del Hombre. El Burgo de Osma, Soria, 1997. Fundación Las Edades del Hombre, [Valladolid].

Lafuente Álvarez, M. 1971: "La villa de Andaluz, su iglesia románica y su fuero", Celtiberia, 42, pp. 191-210.

Lambert, É. 1928: "Les voûtes nerveés hispano-musulmanes du XI siècle et leur influence posible su l'art chretien", Hesperis, 8, pp. 147-175.

Lambert, É. 1935: "L'influence artistique de l'Islam dans les monuments de Soria", en Anuario del Cuerpo Facultativo de Archiveros, Bibliotecarios y Arqueólogos. homenaje a Don José Ramón Mélida y Alinari, 3, pp. 43-50. [s. n.], Madrid.

Lampérez y Romea, V. 1901a: "San Miguel de Almazán”, Boletín de la Sociedad Española de Excursiones, IX, 96, pp. 31-35.

Lampérez y Romea, V. 1901b: "Santa María de Huerta", Boletín de la Sociedad Española de Excursiones, IX, 99, pp. 103-110.

Lampérez y Romea, V. 1904: "Notas sobre algunos monumentos de la arquitectura cristiana española. IX. San Juan de Duero (Soria)", Boletín de la Sociedad Española de Excursiones, XII, 136, pp. 109-114. 
Lampérez y Romea, V. 1908: Historia de la arquitectura cristiana española en la Edad Media, según el estudio de los elementos y los monumentos, tomo 1. José Blass y Cia., Madrid.

Larrén Izquierdo, H. 1984: "Excavaciones arqueológicas en la iglesia de San Miguel de San Esteban de Gormaz (Soria)", en C. de la Casa (coord.), Actas del I Symposium de Arqueología Soriana, pp. 511-522. Diputación Provincial, Soria.

Layna Serrano, F. 1935: La arquitectura románica en la provincia de Guadalajara. Nuevas Gráficas, Madrid.

Lojendio, L. M. de y Rodríguez, A. 1981: Castilla/2. Soria, Segovia, Ávila y Valladolid. Encuentro, D.L., Madrid.

Lorenzo Arribas, J. 2009: "Canecillo de San Miguel de San Esteban de Gormaz (réplica)", en Paisaje interior. Las Edades del Hombre. Soria, concatedral de San Pedro, mayo a diciembre de 2009. Fundación las Edades del Hombre, [Valladolid], pp. 576-578.

Lorenzo Arribas, J. 2012a: "Gaya Nuño, la Virgen románica de Sopeña (San Andrés del Congosto, Guadalajara), y una historia bonita en la Guerra Civil española", Revista de Soria, 177, pp. 29-34.

Lorenzo Arribas, J. 2012b: "La tradición oral como fuente insustituible para la restauración del patrimonio artístico", El Filandar/O Fiadoiro. Publicación Ibérica de Antropología y Culturas Populares, 19, pp. 61-78.

Lorenzo Arribas, J. 2012c: "Fotografía etnográfica en la provincia de Soria. Historia y testimonios conservados en los archivos públicos sorianos", en El tiempo y los ritos. Sueños de plata. Fotografia y antropología en Castilla y León. Zamora, Museo Etnográfico de Castilla y León, pp. 171-207.

Lorenzo Arribas, J. 2013: "Juan Antonio Gaya Nuño y sus estudios sobre el Románico”, en Gaya Nuño. Cien años (1913-2013), pp. 74-85. Soria Edita, Soria.

Lorenzo Arribas, J. 2014: "Encuesta oral”, Románico. Revista de Arte de Amigos del Románico, 18, pp. 68-71.

Madoz Ibáñez, P. 1845-1850: Diccionario geográfico-estadístico-histórico de España y sus posesiones de Ultramar, s.n. Madrid.

Mann, J. 1997: "Romantic Identity, Nationalism, and the Understanding of the Advent of Romanesque Art in Christian Spain", Gesta, 36/2, pp. 156-164.

Manrique Mayor, M. Á., García Encabo, C. y Monge García, J. A. 1989: Inventario artístico de Soria y su provincia. Tomo 1: Arciprestazgos de Abejar, Almajano y Almarza'; tomo II: Arciprestazgos de San Pedro Manrique y Soria. Ministerio de Cultura, Madrid.

Martín Viso, I. 2012: "Paisajes sagrados, paisajes eclesiásticos: de la necrópolis a la parroquia en el centro de la península ibérica", Reti Medievali Rivista, 13/2, pp. 3-45.

Mélida, J. R. 1910a: La iglesia de San Juan de Rabanera en Soria. Nueva Imp. de San Francisco de Sales, Madrid.

Mélida, J. R. 1910b: "Un monumento restaurado: La iglesia de San Juan de Rabanera en Soria”, Boletín de la Sociedad Española de Excursiones, 18/1, pp. 2-20.

Mélida, J. R. 1918: Excavaciones de Numancia. Memoria que de los trabajos realizados en 1916 y 1917 presenta el presidente de la Comisión Ejecutiva de dichas excavaciones. Tip. de la Revista de Archivos, Madrid.

Mélida, J. R. 1923: Excavaciones de Numancia. Memoria acerca de las practicadas en 1920-21. Tip. de la Revista de Archivos, Madrid.

Mélida, J. R. y Taracena, B. 1920: Excavaciones de Numancia. Memoria acerca de las practicadas en 1919-1920. Tip. de la Revista de Archivos, Madrid.

Momplet Míguez, A. E. 1992a: "Filiación hispano-musulmana de abovedamientos románicos y del entorno de 1200 en Castilla y León”, en J. Nuño González (coord.), Alfonso VIII y su época, pp. 295-306. Fundación Santa María la Real, Aguilar de Campoo.

Momplet Míguez, A. E. 1992b: "Caracteres islámicos en la arquitectura medieval castellano-leonesa: abovedamientos 1090-1220”, en Homenaje al profesor Hernández Perera, pp. 93-104. Universidad Complutense, Departamento de Historia del Arte, Madrid.

Monteira Arias, I. 2004: "La influencia islámica en la representación zoomorfa del románico soriano: las aves y su relación con la eboraria hispanomusulmana", Codex aquilarensis, 20, pp. 84-105.
Monteira Arias, I. 2005: "La influencia islámica en la escultura románica de Soria: una nueva vía para el estudio de la iconografía en el románico", Cuadernos de arte e iconografia, 14, 27, pp. 8-244.

Monteira Arias, I. 2012: El enemigo imaginado. La escultura románica hispana y la lucha contra el Islam. CNRS-Université de Toulouse-Le Mirail-Framespa, Toulouse.

Morales Hernández, F. y Borobio Soto, M. ${ }^{a}$ J. 1991: "Resultados de las excavaciones en San Pedro de Caracena (Soria). Junio de 1986. (Una aportación de la Arqueología a la Historia del Arte)", Celtiberia, 81-82, pp. 211-252.

Morales Hernández, F. y Borobio Soto, M. ${ }^{a}$ J. 1992: "Excavaciones arqueológicas en la iglesia de S. Pedro de Caracena (Soria)", en Actas del II Symposium de Arqueología Soriana. Homenaje a Teógenes Ortego y Frías, vol. 2, pp. 1.087-1.105. Diputación Provincial, Soria.

Morales Hernández, F. y Borobio Soto, M. a J. 1995: "Excavaciones arqueológicas realizadas en la iglesia de Ntra. Sra. de la Asunción. Castillejo de Robledo (Soria)", Revista de investigación (Geografia e Historia), 13/2, pp. 99-125.

Olañeta, J. A. 2006: "S.O.S. Alcozar. La ermita de San Esteban Protomártir de Alcozar. Una galería por descubrir", Románico. Revista de Arte de Amigos del Románico, 2, pp. 54-61.

Ortego, T. 1952: "Del románico soriano. Algunas piezas notables de iglesias desaparecidas", Celtiberia, 2, 4, pp. 295-301.

Ortego, T. 1957: "En torno al románico de San Esteban de Gormaz. Una fecha y dos artífices desconocidos", Celtiberia, 13, pp. 79-103.

Ortego, T. 1958: "La ermita hispano-visigoda de la Virgen del Val en Pedro (Soria)", Archivo Español de Arqueología, 21, pp. 223-230.

Ortego, T. 1959: "Las pinturas murales de la iglesia del Rivero en San Esteban de Gormaz", Celtiberia, 17, pp. 127-131.

Ortego, T. 1969: "Del románico soriano. La iglesia de San Bartolomé, en Viana de Duero", Celtiberia, 38, pp. 293-298.

Ortego, T. 1973: Almazán, ilustre villa soriana. Caja General de Ahorros y Préstamos de la Provincia, Madrid.

Ortego, T. 1975: Tiermes. Guía del Conjunto arqueológico. Ministerio de Educación y Cultura, Madrid.

Ortego, T. 1985: “Alcozar, la iglesia de San Esteban ruina histórico-artística de la villa", Celtiberia, 35, 70, pp. 331-338.

Ortego, T. 1987: La ermita mozárabe de San Baudelio en Casillas de Berlanga. Ingrabel Almazán.

Paisaje interior 2009: Paisaje interior. Las Edades del Hombre. Soria, concatedral de San Pedro, mayo a diciembre de 2009. Fundación las Edades del Hombre, [Valladolid].

Pérez-Villamil, M. 1875: Una visita al Monasterio de Huerta. Estab. Tip. M. Pita, Sigüenza.

Ponz, A. 1785: Viage de España, en que se da noticia de las cosas más apreciables y dignas de saberse que hay en ella, tomo 13. Joachín Ibarra, Madrid.

Porter, A. K. 1924: "Spain or Toulouse? and Other Questions", Art Bulletin, 7/1, pp. 3-25.

Porter, A. K. 1926: "Leonesque Romanesque and Southern France", Art Bulletin, 8/4, pp. 235-250.

Porter, A. K. 1928: La escultura románica en España, 2 vols. Pantheon-G. Gili, Firenze/Barcelona.

Quadrado, J. M. y Parcerisa F. J. 1855: Recuerdos y bellezas de España. Asturias y León. Imprenta de Repullés, Madrid.

Quadrado, J. M. y Parcerisa F. J. 1865a: Recuerdos y bellezas de España. Valladolid, Palencia y Zamora. Imprenta de López, Madrid.

Quadrado, J. M. y Parcerisa F. J. 1865b: Recuerdos y bellezas de España. Salamanca, Ávila y Segovia. Imprenta de Luis Tasso, Barcelona.

Quiñones, A. M. '1983: "Ermita de los Santos Mártires de Garray", Celtiberia, 66, pp. 217-232.

Quiñones, A. M. ${ }^{a}$ 1984: "Estudio arquitectónico e iconográfico del pórtico de la iglesia de Omeñaca", Celtiberia, 68, pp. 207-220.

Quiñones, A. M. 1985: "La iglesia de Fuensaúco”, Celtiberia, 70, pp. 253-263.

Rabal, N. 1889: Soria. Daniel Cortezo y Ca., Barcelona.

Ramírez Rojas, T. 1894a: Arquitectura Románica en Soria. Tipografía de Pascual Rioja, Soria. 
Ramírez Rojas, T. 1894b: "Portada de San Nicolás", Recuerdo de Soria, 4, pp. 15-17.

Ramírez Rojas, T. 1907-1908: "San Juan de Otero. Iglesia de los templarios", Boletín de la Sociedad Castellana de Excursiones, III, pp. 33-35.

Ramírez Rojas, T. y Lorenzo, A. de. 1904: "San Juan de Duero", Arquitectura y Construcción, 142, pp. 139-141.

Recio García, T. de la A. 1981: "La iglesia parroquial de Fuentelsaz de Soria", Celtiberia, 61, pp. 73-86.

Resino Toribio, J., Delgado Arceo, M. E., y Villanueva Martín, L. A. 2014: "Historia de una iglesia a la luz de la arqueología; la ermita de Nuestra Señora del Val (Pedro, Soria)", Historia Digital, 14 (24), pp. 5-71.

Rodríguez Montañés, J. M. 2002a: "Panorama general del arte románico en Soria”, en M. Á. García Guinea y J. M. Pérez González (dirs.), Enciclopedia del Románico en Castilla y León, Soria, vol. I, pp. 31-50. Fundación Santa María la Real, Aguilar de Campoo.

Rodríguez Montañés, J. M. 2002b: “Almazán. Iglesia de Nuestra Señora del Campanario”, en M. Á. García Guinea y J. M. Pérez González (dirs.), Enciclopedia del Románico en Castilla y León, Soria, vol. 1, pp. 150-154. Fundación Santa María la Real, Aguilar de Campoo.

Rodríguez Montañés, J. M. 2002c: "Caltojar. Iglesia de San Miguel Arcángel”, en M. Á. García Guinea y J. M. Pérez González (dirs.), Enciclopedia del Románico en Castilla y León, Soria, vol. 1, pp. 297-305. Fundación Santa María la Real, Aguilar de Campoo.

Rodríguez Montañés, J. M. 2002d: "Montejo de Tiermes. Ermita de Santa María de Tiermes”, en M. Á. García Guinea y J. M. Pérez González (dirs.), Enciclopedia del Románico en Castilla y León, Soria, vol. 2, pp. 655-664. Fundación Santa María la Real, Aguilar de Campoo.

Rodríguez Vázquez, J. M. y Garcinuño Callejo, Ó. 2003: “De Románico y románicos: una aproximación a la doble naturaleza del románico popular", Anales de Historia del Arte, 13, pp. 7-25.

Ruiz Ezquerro, J. J. 1990: "Las iglesias de Nafría y Calatañazor (Soria): conjunción de influencias silenses e hispanomusulmanas”, en El románico en Silos. IX centenario de la consagración de la iglesia y claustro, 1088 1988, pp. 575-581. Abadía de Silos, Burgos.

Ruiz Montejo, I. 1980: "Focos primitivos del románico castellano. Cronología y nuevos planteamientos de taller. Una aproximación a la problemática de los pórticos", Goya, 158, pp. 86-93.

Ruiz Montejo, I. 1989: "Concepto y método del románico rural”, Anales de Historia del Arte 1, 21-37.

Saavedra, E. 1856: "San Juan de Duero, en Soria", Revista de Obras Públicas, IV, 24, pp. 277-282.

Saavedra, E. 1859: "San Nicolás en Soria”, Revista de Obras Públicas, 7, 24, pp. 289-293.

Sáinz Magaña, M. E. 1983: "Estudio iconológico y simbólico de la fachada de Santo Domingo (Soria)", Celtiberia, 33, 66, pp. 363-372.

Sáinz Magaña, M. E. 1984: "Los tímpanos de la iglesia de Tozalmoro: reflejo ruralizado de los tímpanos de la ciudad de Soria”, Celtiberia, 34, 68, pp. 221-226.

Sáinz Magaña, M. E. 1990: "Silos y el románico soriano”, en El románico en Silos. IX centenario de la consagración de la iglesia y claustro, 10881988, pp. 429-435. Abadía de Silos, Burgos.

Salgado Pantoja, J. A. 2012: "Las galerías porticadas de San Esteban de Gormaz: legado artístico de una sociedad de frontera", Liño, 18, pp. 19-29.

Sentenach, N. 1911: "Excursión a Termes", Boletín de la Sociedad Española de Excursiones, 19/3, pp. 176-190.

Sobrino González, M. 2013: "De las canonjías de Segovia a la casa de San Blas de Soria. Aspectos del románico civil en Castilla y León”, en P. Navascués Palacio, y S. Huerta Fernández (coords.), Segovia, su catedral y su arquitectura: Ensayos en homenaje a José Antonio Ruiz Hernando, pp. 211-235. Instituto Juan de Herrera, Madrid.
Soria Románica 2001: Soria Románica. El Arte románico en la Diócesis de Osma-Soria. Catálogo de la exposición. S.I. Catedral de Nuestra Señora de la Asunción de El Burgo de Osma, 27 de junio al 30 de septiembre de 2001. Gondo, Seseña (Toledo).

Taracena Aguirre, B. 1926: Excavaciones en la provincia de Soria. Memoria de los resultados obtenidos en 1924. Revista de Archivos, Madrid.

Taracena Aguirre, B. 1927: Excavaciones en las provincias de Soria y Logroño. Memoria de las excavaciones practicadas en 1925-26. Tip. de la Revista de Archivos, Madrid.

Taracena Aguirre, B. 1929: Excavaciones en las provincias de Soria y Logroño. Memoria de las excavaciones practicadas en 1928. Tip. de la Revista de Archivos, Madrid.

Taracena Aguirre, B. 1932: Excavaciones en la provincia de Soria. Memoria. Tip. de Archivos, Madrid.

Taracena Aguirre, B. 1933: "Notas de arquitectura románica. Las galerías porticadas", Boletín de la Biblioteca Menéndez y Pelayo, 9, pp. 3-18.

Taracena, B. y Tudela, J. 1928: Soria. Guía artística de la ciudad y provincia. Imp. Las Heras, Soria.

Taracena, B. y Tudela, J. 1997: Soria. Guía artística de la ciudad y provincia. 6 a edición. Diputación Provincial, Soria.

Torres Balbás, L. 1940: "La influencia artística del Islam en los monumentos de Soria", Al-Ándalus, 5, pp. 465-467.

Yusta Bonilla, J. F. 1993: "La iglesia de San Miguel de Andaluz (Soria), de la singularidad al tipo", III Simposi sobre Restauración Monumental (Barcelona, del 19 al 21 de noviembre de 1992), pp. 197-204. Diputació Provincial, Barcelona.

Yusta Bonilla, J. F., Diestro Ortega, F., Esteras Martínez, J. Á., Gonzalo Cabrerizo, C. y Lorenzo Arribas, J. 2010: "Estrategia de actuación ante una ruina románica. La ermita de la Virgen del Vallejo en Alcozar (Soria)", en VI Congreso Internacional 'Restaurar la memoria'. La gestión del Patrimonio hacia un planteamiento sostenible [AR\&PA, 31 octubre-2 noviembre de 2008. Valladolid], tomo 2, pp. 45-50. Junta de Castilla y León, Salamanca.

Yusta Bonilla, J. F., Esteras Martínez, J. Á., Gonzalo Cabrerizo, C., Lorenzo Arribas, J. y Santa-Olalla Carcedo, I. 2010: "Románico desconocido. La iglesia del despoblado de Alconeza, Soria”, en VI Congreso Internacional 'Restaurar la memoria'. La gestión del Patrimonio hacia un planteamiento sostenible [AR\&PA, 31 octubre-2 noviembre de 2008. Valladolid], tomo 2, pp. 51-61. Junta de Castilla y León, Salamanca.

Yusta, J. F., Arévalo, B., Gonzalo, C., Frías, C., Santa-Olalla, I., Ruiz, C., Borque, J.M., Diestro, F., Sanz, L.M. y Lorenzo, J. 2013: "La piel que habla. La iglesia de San Miguel en San Esteban de Gormaz (Soria)", en S. Mora, A. Rueda y P. A. Cruz (eds.), La experiencia del reúso. Propuestas Internacionales para la Documentación, Conservación y Reutilización del Patrimonio Arquitectónico, vol. 3, pp. 381-388. c2o, Servicios editoriales, Madrid.

Yusta, J. F., Santa-Olalla, I. y Lorenzo, J. 2013: “Después de intervenir ¿qué? Propuestas para tres ermitas sorianas: Virgen de Lagunas (Villálvaro), Ntra. Sra. de la Dehesa (Velamazán) y Virgen del Val (Pedro)", en S. Mora, A. Rueda y P. A. Cruz (eds.), La experiencia del reúso. Propuestas Internacionales para la Documentación, Conservación y Reutilización del Patrimonio Arquitectónico, vol. 1, pp. 503-510. c2o, Servicios editoriales, Madrid.

Zamora Lucas, F. 1951: "Un monasterio cisterciense en Tardesillas (12121285)", Celtiberia, 1, pp. 81-98.

Zamora Lucas, F. 1952: "Monasterio de Santa María de Tera (927-1166)", Celtiberia, 3, pp. 85-86.

Zamora Lucas, F. 1953: "Monasterios sorianos de la Edad Media", Celtiberia, 5, pp. 91-100. 